Santa Clara Law

Santa Clara Law Digital Commons

$1-1-1985$

\title{
Actions for Nonphysical Harm: The Relationship Between the Tort System and No-Fault Compensation (With an Emphasis on Workers' Compensation)
}

Jean C. Love

Santa Clara University School of Law, jlove@scu.edu

Follow this and additional works at: http://digitalcommons.law.scu.edu/facpubs

\section{Recommended Citation}

73 Cal. L. Rev. 857

This Article is brought to you for free and open access by the Faculty Scholarship at Santa Clara Law Digital Commons. It has been accepted for inclusion in Faculty Publications by an authorized administrator of Santa Clara Law Digital Commons. For more information, please contact sculawlibrarian@gmail.com. 


\title{
Actions for Nonphysical Harm: The Relationship Between the Tort System and No-Fault Compensation (With an
} Emphasis on Workers' Compensation)

\author{
Jean C. Love $\dagger$
}

Dissatisfaction with the tort system's fault-based method of compensating for personal injuries has led to the enactment of workers' compensation legislation by every jurisdiction in the United States. ${ }^{1}$ It has also prompted New Zealand to adopt a comprehensive no-fault plan for any type of personal injury caused by accident, whether sustained on the job or elsewhere. ${ }^{2}$ These no-fault plans adopted by the Umited States and New Zealand have several common features: compensation may be obtained without proof of fault, no-fault benefits are lower in amount than the dainages recoverable at common law, and no-fault compensation is often a complete substitute for tort recovery.

When no-fault legislation was originally enacted in the United States and New Zealand, the focus was on providing adequate compensation for

$\dagger$ Professor of Law, School of Law, University of California, Davis. B.A. 1965, J.D. 1968, University of Wisconsin. This Article is based in part on research undertaken while I was a Fulbright-Hays Senior Scholar in residence at Victoria University of Welhington, New Zealand, in 1978. The research was updated in 1982, when I returned to Wellington under a Research Development Award from the University of California, Davis. I am grateful to my colleague, Alan Brownstein, for his valuable comments on earher drafts of this article. I am also indebted to my research assistants Lisa Tillman, Benna Troup, and Connie Zanglis.

1. 1 A. Larson, The Law of Workmen's Compensation $\$ 5.30$ (1984); Epstein, The Historical Origins and Economic Structure of Workers' Compensation Law, 16 GA. L. REV. 775 (1982); Larson, The Nature and Origins of Workmen's Compensation, 37 CORNELL L.Q. 206 (1952). Workers' compensation legislation is a no-fault plan that conpensates for employment-related death or injury. For a discussion of workers' compensation legislation in other countries, see Flening, Tort Liability for Work Injury in 15 INTERNATIONAL ENCYCLOPEDIA OF COMPARATIVE LAW 9-1 to $9-46$ (1975).

2. Accident Conipensation Act of 1972, [1975] 2 N.Z. Stat. 1409, amended by Accident Compensation Act of 1982, [1982] 3 N.Z. Stat. 1554. See generally M. BERKOWITZ, THE EconOMICS OF WORK ACCIDENTS IN NEW ZEALAND (1979); A. BLAIR, ACCIDENT COMPENSATION IN NEW ZEALAND (1978); T. IsON, ACCIDENT COMPENSATION: A COMMENTARY ON THE NEW ZEALAND SCHEME (1980); G. PALMER, COMPENSATION FOR INCAPACITY: A STUdY OF LAW AND Social Change in New Zealand and Australia (1979); Henderson, The New Zealand Accident Compensation Reform, 48 U. CHI. L. REv. 781 (1981). 
negligently inflicted pliysical injury. ${ }^{3}$ Legislative bodies did not consider whether no-fault plans should cover claims for pure nonplysical harm, and the plans were silent on the subject. ${ }^{4}$ As a result, wlien claimants subject to such no-fault legislation bring tort actions for pure nonphysical harm, the courts liave two basic options. First, the judiciary may construe a no-fault plan as implicitly covering claims for nonphyical harm. That option would bar tort actions for such harm, even though the nofault plan may not adequately compensate for nonphysical injuries. Second, the judiciary may construe a no-fault plan as explicitly covering only claims for physical injury. This would permit the victim of a nonphysical injury to pursue a common law tort action outside the framework of the no-fault plan.

In recent years, an mcreasing volume of litigation has raised the question of whether no-fault legislation should be construed to cover pure nonphysical harm. ${ }^{5}$ A review of the current case law indicates that the judiciary generally prefers the tort forum for dignitary harms, such as false imprisonment, ${ }^{6}$ defamation, ${ }^{7}$ civil rights violations, ${ }^{8}$ invasions of privacy, ${ }^{9}$ and retaliatory discharge. ${ }^{10}$ The courts are inore evenly split with respect to actions for emotional distress, such as the intentional infliction of emotional distress and the bad-faith refusal to pay a workers' compensation claim. ${ }^{11}$ Some courts hold that no-fault legislation provides the exclusive remedy, even though the benefits do not adequately compensate for general einotional distress. ${ }^{12}$ Others allow recovery in tort in order to protect fully the plaintiff who has suffered general emotional distress. ${ }^{13}$ In response to this recent litigation, a few legislatures have amended their no-fault statutes to explicitly include or exclude cov-

3. G. PALMER, supra note 2, at 23-32, 214-43; Larson, supra note 1, at 209-11.

4. See generally 2A A. LARSON, supra note $1, \S 68.30$ (1983). By contrast, the drafters of nofault legislation did consider the question of whether to compensate for the pain and suffering or dignitary harm resulting from negligently infiicted physical injuries. In the United States, compensation for such nonphysical harm associated with physical injury is generally denied by workers' compensation legislation. 1 A. LARSON, supra note $1, \S 1.10$, at 1-2 (1984). In New Zealand, a lump sum benefit of up to $\$ 10,000$ is available for such nonphysical harm as pain and suffering and loss of amenities. Accident Compensation Act of $1982 \S 79$, [1982] 3 N.Z. Stat. 1552. This Article does not consider the question of whether persons other than the employee should be able to bring tort actions against the employer for pure nonphysical harm caused by the employee's death or injury (e.g., actions for loss of consortium, wrongful death, or for the infliction of emotion distress on a bystander).

5. 2A A. LARSON, supra note $1, \S \S 68.30-36$ (1983).

6. See infra text accompanying notes 174-91.

7. See infra text accompanying notes 192-211.

8. See infra text accompanying notes 212-53.

9. Id.

10. Annot., 32 A.L.R.4th 1221 (1984).

11. See infra text accompanying notes 254-302.

12. See infra text accoinpanying notes $261-63,285-89$.

13. See infra text accompanying notes $266-70,290-300$. 
erage of claims for certain types of nonphysical harm, but such legislation is still relatively rare. ${ }^{14}$

The problem with the current case law is that the courts have not formulated any consistent theory of tort recovery. Sometimes they permit the claimant to pursue both no-fault benefits and tort damages; sometimes they permit recovery of either no-fault benefits or tort damages. Recent amendments to workers' compensation plans have compounded the problem by expanding no-fault coverage to encompass occupational diseases and mental disabilities. ${ }^{15}$ Unfortunately, these modifications were enacted without consideration of their impact on actions for dignitary harm and general emotional distress.

This Article will examine the judicial opinions that have considered whether no-fault legislation covers claims for pure nonphysical harm, or whether such claims should be litigated as tort actions. First, the Article summarizes the three theories of statutory construction that courts currently einploy to permit tort recovery for dignitary harm and general emotional distress. Second, it apphies those theories to selected actions for nonphysical harm in order to demonstrate their strengths and weaknesses. Finally, the Article offers proposals for legislative reform of nofault plans. It suggests a broad spectrum of amendments that would exphicitly permit tort recovery in actions for dignitary harm and general emotional distress. Enactment of the proposed reforms would help to clarify this murky area of no-fault compensation legislation.

This Article does not explore the question of whether tort liability for pure nonphysical harm should be replaced by a no-fault compensation plan. That topic has been explored elsewhere in this symposium. ${ }^{16}$ This Article assumes no alteration in the existing coverage of no-fault compensation legislation. Instead, it suggests various ways in which tort liability might augment current no-fault plans. ${ }^{17}$ Allowing supplemental tort recovery for pure nonphysical harm can serve to vindicate and compensate the plaintiff's dignitary imterests. It can also deter the infliction of nonphysical harm and pumish those who maticiously interfere with another person's civil rights, privacy rights, or other dignitary interests. Thus this Article envisions that no-fault plans will be the primary source

14. E.g., CAL. Lab. CODE $\S 3602$ (West Supp. 1984); Wis. STAT. ANN. § 102.18(1)(bp) (West Supp. 1984).

15. 1B A. LARSON, supra note $1, \S \S 41.10-.40,42.20-24$ (1982).

16. Sugarman, Doing Away With Tort Law, 73 CALIF. L. REv. 555, 660 (1985).

17. See generally AMERICAN BAR ASs'N, TOWARDS A JURISPRUDENCE OF INJURY: THE CONtinuing CREation of a SYSTem of Substantive Justice in AMERican TORT LAW (1984); Fleming, supra note 1, at 9-1, 9-36 to 9-42 ; Fleming, Is There a Future for Tort?, 58 AusTL. L.J. 131 (1984); Love, Punishment and Deterrence: A Comparative Study of Tort Liability for Punitive Damages Under No-Fault Compensation Legislation, 16 U.C.D. L. REV. 231 (1983); Pedrick, Does Tort Law Have a Future?, 39 OHIO ST. L.J. 782 (1978). 
of compensation for physical injuries and for physical or mental disabilities, whereas tort liability will be the source of compensation for any pure nonphysical harm that is not covered by workers' compensation legislation. In addition, tort habihity will be authorized to punish and deter egregious wrongdoers. ${ }^{18}$

\section{I \\ THEORIES OF TORT RECOVERY}

There are two theories of statutory construction which the courts have used to authorize tort recovery for both physical and nonphysical harm after the enactment of a no-fault plan: the cumulative action theory and the alternative action theory. The cumulative action theory permits a cause of action for tort damages in addition to a claim for no-fault benefits. The benefits are set off agamst the tort judgment to avoid double recovery. ${ }^{19}$ Under the alternative action theory, a tort action is authorized in lieu of no-fault compensation. ${ }^{20}$ Some jurisdictions permit the mjured party to elect between no-fault benefits and tort damages, but usually the judiciary or the agency administering the no-fault statute makes the choice pursuant to legislative guidehnes. ${ }^{21}$

A third theory, which I will call the cumulative remedy theory, has recently emerged, particularly in actions for nonphysical harm. Courts applying this theory permit the injured person to split the cause of action. The plaimtiff then may recover no-fault benefits up to the statutory maximum for the types of harm covered by the statute and tort damages, includimg punitive damages, for all other types of harm. ${ }^{22}$ The cumulative remedy theory differs from the cumulative action theory in that it prohibits the recovery of tort damages for any type of harm that is covered by a no-fault plan. The cumulative remedy theory differs from the alternative action theory in that it authorizes tort damages as a supplemental remedy, rather than as an alternative to no-fault benefits.

The differences between these tliree theories can be further illuminated by the following hypothetical. Imagine that a woman was sexually

18. I developed a similar thesis in an earlier article which proposes that tort actions for punitive damages be allowed to coexist with no-fault compensation benefits. That article focuses on tort actions by claimants who sustained physical imjuries. Love, supra note 17.

19. See infra text accompanying notes 23-46. See generally Note, Exceptions to the Exclusive Remedy Requirements of Workers' Compensation Statutes, 96 HARV. L. REv. 1641, 1652-53 (1983); Note, Intentional Torts Under Workers' Compensation Statutes: A Blessing or a Burden? 12 HOFSTRA L. REv. 181, 202-07 (1983); Note, Intentional Employer Torts: A Matter for the California Legislature, 15 U.S.F.L. REv. 651, 678-84 (1981).

20. See infra text accompanying notes 47-139. See generally Note, Judicial Misapplication of the Indiana Workmen's Compensation Act to Injuries Resulting from an Employer's Wilful Conduct, 13 VAL. U.L. REV. 561, 582-87 (1979).

21. Love, supra note 17 , at $258-73$.

22. See infra text accompanying notes 140-73. 
harassed by her employer and suffered both physical and nonphysical injuries. Under the cumulative action theory, the victim would receive no-fault benefits - limited compensation for economic loss - as reimbursement for her physical and mental disabilities. She would also be permitted to recover unlimited compensatory tort damages for her medical expenses, lost earning capacity, pain and suffering, and pure nonphysical liarm. In addition, slie could recover punitive damages upon proof of malicious misconduct. Her tort recovery would be reduced by the amount of her no-fault benefits. Under the alternative action theory, the victim would receive either no-fault benefits or tort damages. Under the cumulative remedy theory, the victim would receive no-fault benefits (limited compensation for economic loss) as reimbursement for her physical and mental disabilities. In addition, she could sue in tort for her pure nonphysical harm and for punitive damages. She would be prohibited from recovering tort damages for her medical expenses, lost earning capacity, and pain and suffering because these types of harm are covered by the no-fault plan.

In a few jurisdictions, statutes have authorized the three theories of tort recovery discussed in this Part of the Article. Those statutes will be discussed at the beginning of each Section. In most jurisdictions, however, the courts have developed the theories, and therefore the primary focus of this Part is on judicial opinions.

\section{A. Cumulative Action}

Three states (Oregon, Washington and West Virginia) have enacted workers' compensation legislation authorizing a cumulative tort action for acts done by an employer with the "deliberate intention" to cause personal "injury or death."23 The phrase "deliberate intention" has been interpreted to mean that the employer acted with a "consciously, subjectively and deliberately formed intention to produce the specific result of injury or death to an employee."24 The primary purpose of these statutes

23. The West Virginia statute provides:

If injury or death result to any employee from the deliberate intention of his employer to produce such injury or death, the employee. . . sliall liave the privilege to take under this chapter, and shall also have cause of action against the employer, as if this chapter liad not been enacted, for any excess damages over the amount received or receivable under this chapter.

W. VA. CODE $\S 23-4-2$ (b) (Supp. 1984). Accord OR. REv. STAT. § 656.156 (1983); Wash. ReV. CODE ANN. $\$ 51.24 .020$ (Supp. 1985). See generally Love, supra note 17, at 252-57. For a discussion of the policy considerations that justify a statutory cumulative tort action, see Newby v. Gerry, 690 P.2d 603, 607-09 (Wash. Ct. App. 1984) (tort action against co-employee).

24. W. VA. CODE $\$ 23-4-2$ (c)(2)(i) (Supp. 1984). This statutory definition was enacted to override Mandolidis v. Elkins Indus., 161 W. Va. 695, 705, 246 S.E.2d 907, 914 (W. Va. 1978), which liad construed the phrase "deliberate intention" to encompass both intentional and reckless misconduct. 
is to provide additional compensation and punitive damages to the victims of deliberately inflicted physical injury or death.

No plaintiff has successfully invoked any of these statutes in seeking tort recovery for purely nonphysical harm. ${ }^{25}$ Moreover, even if a court were willing to construe the term "injury" to cover pure nonphysical harm, the plaintiff's opportumity to recover under the statute would still be severely restricted by the specific intent requirement. Nevertheless, these statutory causes of action have inspired the California judiciary to develop the cuinulative action theory as a basis for awarding damages for nonphysical harm to einployees.

The first California case to recognize the cuinulative action theory was Unruh v. Truck Insurance Exchange. ${ }^{26}$ The plaintiff charged that a workers' compensation insurer had harassed her in an outrageous manner during its investigation of her successful claim. ${ }^{27}$ The California Supreme Court allowed her to bring a tort action for assault, battery and the intentional infliction of enotional distress. A California statute granted the workers' compensation insurer immunity from suit by an employee who had received workers' compensation benefits. ${ }^{28}$ The court held, however, that the insurer could not imvoke the statutory immunity when, "as in the instant case, . . . such insurer intentionally embarks upon a deceitful course of conduct in its investigation which causes injury to the subject of the investigation."29 The court distinguished between neghigent and intentional misconduct and concluded that an action at law for the insurer's intentional torts would not impair the objective of workers' coinpensation legislation. ${ }^{30}$

The Unruh court apphed the cumulative action theory to "intentional" misconduct. Subsequent decisions by the California courts of appeal ${ }^{31}$ have confined the theory to cases involving "fraudulent, deceit-

25. In Hardy v. State, 38 Wash. App. 399, 685 P.2d 610 (1984), the plaintiff sought to recover tort damages for general harassment under the Washington statute, but her claim was denied because she failed to prove that the alleged harasser had acted within the scope of his employment.

26. 7 Cal. 3d 616, 498 P.2d 1063, 102 Cal. Rptr. 815 (1972). The court's adoption of the cumulative action theory permitted the plaintiff to recover tort damages despite the exclusive remedy provisions of California's workers' compensation legislation. See generally Love, supra note 17, at 257-62.

27. Unruh, 7 Cal. 3d 616, 498 P.2d 1063, 102 Cal. Rptr. 815 (1972).

28. CaL. LAB. CoDE $\S \S 3850,3852$ (West 1971 \& Supp. 1984).

29. Unruh, $7 \mathrm{Cal}$. 3d at 630, 498 P.2d at 1073, $102 \mathrm{Cal}$. Rptr at 825 .

30. Id.

31. Argonaut Ins. Co. v. Superior Court, 164 Cal. App. 3d 320, 210 Cal. Rptr. 417 (1985); Denning v. Esis Corp., 139 Cal. App. 3d 946, 189 Cal. Rptr. 118 (1983); Droz v. Pacific Nat'1 Ins. Co., 138 Cal. App. 3d 181, 188 Cal. Rptr. 10 (1983); Depew v. Hartford Accident \& Indem. Co., 135 Cal. App. 3d 574, 185 Cal. Rptr. 472 (1982); Fremont Indem. Co. v. Superior Court, 133 Cal. App. 3d 879, 184 Cal. Rptr. 184 (1982); Ricard v. Pacific Indem. Co., 132 Cal. App. 3d 886, 183 Cal. Rptr. 502 (1982); Everfield v. State Compensation Ins. Fund, 115 Cal. App. 3d 15, 171 Cal. Rptr. 164 (1981). 
ful, outrageous, [or] perfidious" tortious acts by the insurer. ${ }^{32}$ Thus, unless the California Supreme Court reiterates the broad test of intent articulated in Unruh, this judicially recognized tort action will require the same proof of specific intent as is currently required by the Oregon, Washington and West Virginia statutes. ${ }^{33}$

The California Supreme Court has also recognized the cumulative action theory in a case of employer misconduct. In Johns-Manville Products Corp. v. Superior Court, ${ }^{34}$ it held that an employee seeking workers' compensation benefits for a disability caused by exposure to asbestos could simultaneously bring a tort action for aggravation of the disease resulting from the employer's fraudulent concealment of the fact that the plaintiff had asbestosis. The court perceived a trend toward allowing an action at law for injuries suffered in employment "if the employer acts deliberately for the purpose of imjuring the employee or if the harm resulting from the intentional misconduct consists of aggravation of an initial work-related injury." 35

The supreme court's phraseology is strikingly similar to the language of the Oregon, Washington and West Virginia statutes, ${ }^{36}$ which appears to focus on physical injury. However, one court of appeal in California has extended the Johns-Manville doctrine to an action for nonphysical harm caused by an employer. In $M c G e e$ v. McNally, ${ }^{37}$ the court held that the victim of a "campaign of harassment designed by his supervisors to deprive him of his job" could bring a tort action for intentional infliction of emotional distress ${ }^{38}$ even though he also was entitled to workers' compensation benefits for the physical harm caused by the harassment. ${ }^{39}$ Citing Johns-Manville, the court found that workers' compensation "was not imtended to preclude certain actions based on rare instances of malicious oppression." 40

The Califorma judiciary's development of a cumulative action theory has now been endorsed, at least in part, by the California legislature. ${ }^{41}$ In 1982, the legislature amended the workers' compensation

32. Everfield v. State Compensation Ins. Fund, 115 Cal. App. 3d 15, 19, 171 Cal. Rptr. 164, 165 (1981).

33. See supra note 23.

34. 27 Cal. 3d 465, 612 P.2d 948, 165 Cal. Rptr. 858 (1980) (The workers' compensation benefits sought by the employee covered both the injury from the original exposure to asbestos and the aggravation of the disease caused by the employer's fradulent conduct.).

35. Id. at 476,612 P.2d at 955,165 Cal. Rptr. at 865 .

36. See supra note 23.

37. 119 Cal. App. 3d 891, 174 Cal. Rptr. 253 (1981).

38. Id. at 893-95, $174 \mathrm{Cal}$. Rptr. at 254-55.

39. Id. at 894-95, $174 \mathrm{Cal}$. Rptr. at 255.

40. Id. at 895, 174 Cal. Rptr. at 256; see also Young v. Libby-Owens Ford Co., 214 Cal. Rptr. 400 (Cal. Ct. App. 1985) (action for "intentional" infliction of emotional distress, assault, and battery).

41. Cal. Lab. Code $\S 3602$ (West Supp. 1985). 
statute to allow an employee to bring an action at law against an employer, even after recovering workers' compensation benefits, in the following instances:

(1) Where the employee's injury or death is proximately caused by a willful physical assault by the employer. (2) Where the employee's injury is aggravated by the employer's fraudulent concealment of the existence of the injury and its connection with the employment, in which case the employer's hability shall be hmited to those damages proximately caused by the aggravation. ...42

Although the statute clearly codifies Johns-Manville, it falls short of codifymg Unruh's recogmition of a cumulative cause of action for any intentional misconduct. The first section of the statute neither defines "willful" nor specifies whether the injury caused by the "physical assault" must also be physical. ${ }^{43}$ Furtherinore, it is unlikely that the statute would perınit recovery in a case like $M c G e e$, where the harm was caused by a "campaign of harassment."44 The second part of the statute is worded clearly, but the scope of the terin "injury" is undefined. The California legislation may thus be construed expansively to provide a statutory basis for the courts to allow cumulative actions for nonphysical harm, at least in actions for fraudulent concealment. Alternatively, the statute inay be interpreted restrictively to permit cumulative actions only for physical harm caused by willful misconduct or aggravated by fraudulent concealment of the existence of an injury.

This examination of the California case law demonstrates the limitations of the cumulative action theory as apphed to tort actions for nonphysical harn. The theory allows recovery only for egregious misconduct. Even though many actions for nonphysical harm are intentional tort actions, it will usually be difficult to prove that the defendant "consciously, subjectively and deliberately"45 intended to cause nonphysical harm to the plaintiff or engaged in "fraudulent," "perfidious" or "outrageous" conduct. ${ }^{46}$

\section{B. Alternative Action}

The alternative action theory mandates a choice between a tort claim and no-fault benefits. In this way it is more limited than the cumulative action theory. On the other hand, the alternative action theory is

42. Id.

43. In Iverson v. Atlas Pac. Eng'g, 143 Cal. App. 3d 219, 225, 191 Cal. Rptr. 696, 700 (1983), the court construed an exception to California's exclusive remedy clause for a willful "physical act of aggression." The court held the exception required proof of a physical act causing a reasonable fear of harm, but held that "the resulting harm need not also be physical."

44. See supra text accompanying notes $37-40$.

45. See supra text accompanying notes $23-24$.

46. See supra text accompanying notes 31-32. 
broader than the cumulative action theory insofar as it may permit a tort claim for intentional employer misconduct that involves neither a specific intent to injure nor outrageous misconduct. This section will explore the various statutory and judicial permutations of the alternative action theory.

\section{Statutory Cause of Action}

Seven jurisdictions in the United States have statutes creating an alternative tort action in cases of intentional misconduct by the employer. Three of these states have legislation that gives the employee an explicit option:

If injury or death results to an employe[e] through the deliberate intention of his employer to produce such injury or death, the employe[e] or his dependents inay take under this chapter, or in heu thereof, have a cause of action at law against the employer as if this chapter had not been passed . . . .47

Three other states have created statutory exceptions to their exclusive remedy clauses for "intentional" torts, ${ }^{48}$ wrongs ${ }^{49}$ or acts. ${ }^{50}$ One state has authorized an alternative tort action for "wilful or unprovoked physical aggression." 51

The statutory alternative tort actions have proven to be no more useful to victims of nonphysical harm than the statutory cumulative tort actions discussed in the preceding section. It is questionable whether the statutory exceptions are applicable to actions for nonphysical injuries. ${ }^{52}$ If so, proof of specific intent to harm is usually required. ${ }^{53}$ Not surprisingly, then, all but on ${ }^{54}$ of the cases from these seven jurisdictions that have allowed tort actions for nonphysical harm have permitted recovery

47. Ky. Rev. Stat. ANN. $\$ 342.610(4)$ (Michie 1983). Accord MD. ANN. Code art. 101, $\S 44$ (1957). The Arizona statute is worded somewhat differently:

A. The right to recover compensation pursuant to this chapter for injuries sustained by an employee . . . is the exclusive remedy against the employer . . . . except that if the injury is caused by the employer's wilful misconduct, . . . and the act causing the injury is the personal act of the employer, . . . and the act indicates a wilful disregard of the life, limb or bodily safety of employees, the injured employee inay either claim compensation or unaintain an action at law for damages....

B. "Wilful misconduct" as used in this section means an act done knowingly and purposely with the direct object of injuring another.

Ariz. Rev. Stat. ANN. § 23-1022 (Supp. 1984-1985).

48. S.D. CoDIFIED LAwS ANN. § 62-3-2 (1978).

49. N.J. STAT. ANN. $§ 34: 15-8$ (West Supp. 1984-1985).

50. LA. Rev. Stat. ANN. $\S 23: 1032$ (West Supp. 1984).

51. IDAHO CODE $§ 72-209$ (1973).

52. E.g. Yeend v. United Parcel Serv., Inc., 104 Idaho 333, 335-37, 659 P.2d 87, 89-91 (1982)

(Huntley, J., dissenting).

53. See generally Love, supra note 17, at 263-64.

54. Maggio v. St. Francis Medical Center, Inc., 391 So. $2 d 948$ (La. Ct. App. 1980), cert. denied, 396 So. 2d 1351 (La. 1981). 
in spite of, rather than in reliance upon, the statutory provisions. ${ }^{55}$

Instead of requiring proof of specific intent pursuant to the statutory provisions, the cases have recognized an alternative tort action based on the theory that an action for nonphysical harm lies outside the scope of the workers' compensation plan, and thus is unaffected by the exclusive remedy clause. ${ }^{56}$ For example, in Columbia Sussex Corporation v. Hay, ${ }^{57}$ a Kentucky court permitted the plaintiff to bring tort actions for false imprisonment and slander per se against her employer. The court interpreted the Kentucky statute quoted in the opening paragraph of this Section as authorizing a tort action only if the plaintiff's injury resulted from "willful and physical aggression." 58 It then held that the plaintiff did not have to fit her case within the language of the statute because

[t] he purpose of Workers' Compensation is to redress physical and mental mjuries and damages arising from the employment relationship. The crux of a slander per se action is not injury, for no actual damages are required to be shown. Likewise, false imprisonment stands or falls upon elements which may result in damages, but again such are not requisite for a prima facie case. ${ }^{59}$

Since the plaintiff could allege a prina facie tort action without proof of actual harm, there was "nothing for which the Workers' Coinpensation Act would compensate." 60 Therefore, the plaintiff was free to proceed in a tort action outside the scope of the workers' compensation legislation. Had her imjury come within the scope of the no-fault plan, her tort action would have been barred because she would have been unable to prove the "willful and physical aggression" required to bring her action within the statutory exception to the exclusive reinedy clause.

In another case, ${ }^{61}$ the Eighth Circuit held that a plaintiff could bring a tort action against her employer and its workers' coinpensation carrier for their bad-faith refusal to pay workers' compensation benefits. The plaintiff sought to rely ${ }^{62}$ on the South Dakota statute creating an exception to the workers' compensation exclusive remedy clause in cases of "intentional wrongdoing." 63 Instead, the court allowed the plaintiff to sue in tort by holding that her action fell outside the scope of the workers' compensation legislation because the statute does not cover "torts

55. See infra text accompanying notes 57-64.

56. See infra text accompanying notes 98-118. The technique of statutory construction employed by these courts is discussed more fully infra in the text accompanying notes 76-139.

57. 627 S.W.2d 270 (Ky. Ct. App. 1981).

58. Id. at 278.

59. Id. at 279.

60. Id.

61. Hollman v. Liberty Mut. Ins. Co., 712 F.2d 1259 (8th Cir. 1983).

62. Id. at $1261 \mathrm{n} .4$.

63. S.D. CODIFIED LAWS ANN. § 62-3-2 (1978). 
which occur independent of the industrial injury."64

In only one case, Maggio v. St. Francis Medical Center, Inc. ${ }^{65}$ has a court from one of these seven jurisdictions rehed on the statutory alternative action to permit the plaintiff to sue in tort for nonphysical harm. The Louisiana workers' compensation statute provides: "Nothing in this Chapter shall affect the liability of the employer . . ., civil or criminal, resulting from an intentional act." 66 In Maggio, the court held the plaintiff had satisfied the "intentional act" requirement by alleging that the defendant engaged in a "pattern of outrageous, harassing conduct" of such a nature as "to necessarily be calculated and intended to inake plaintiff's working conditions unbearable and to cause him mental and einotional distress." 67

Although the courts in these seven jurisdictions usually have not chosen to rely upon the statutes authorizing alternative tort actions in permitting recovery for nonphysical harm, the legislation could be invoked in future cases. The statutes wlich courts currently imterpret to require proof of intent to cause physical injury ${ }^{68}$ could be construed to permit proof of specific intent to cause either physical or nonphysical harm. ${ }^{69}$ In addition, the exclusive remedy clauses that create exceptions for "intentional" torts, wrongs or acts ${ }^{70}$ could readily be interpreted to allow actions for nonphysical harm, as in Maggio. ${ }^{71}$ Even the Idaho exclusive remedy clause, whicl creates an exception for "willful or unprovoked physical aggression,"72 could be constrned to allow certain intentional nonphysical tort actions. For example, the dissenting judge in Yeend v. United Parcel Service, Inc. ${ }^{73}$ suggested that the Idaho statute should be interpreted to allow actions for the intentional infliction of emotional distress because

[the] statute was enacted at a time in Idaho history when we did not have a common law cause of action for "intentional or reckless infliction of

64. Hollman, 712 F.2d at 1261 .

65. 391 So. $2 d 948$ (La. Ct. App. 1980).

66. LA. Rev. STAT. ANN. § 23:1032 (West Supp. 1984).

67. 391 So. $2 d$ at 950.

68. See supra text accompanying note 47.

69. E.g., Thompson v. Maimonides Medical Center, 86 A.D.2d 867, 447 N.Y.S.2d 308 (1982).

70. See supra text accompanying notes 48-50.

71. Maggio v. St. Francis Medical Center, Inc., 391 So. 2d 948 (La. Ct. App. 1980). The Louisiana Supreme Court has ruled that plaintiffs may bring alteruative tort actions based on proof of either deliberate or constructive intent:

The meaning of "intent" is that the person who acts either (1) consciously desires the physical result of his act, whatever the likelihood of that result happening from his conduct; or (2) knows that that result is substantially certain to follow from his conduct, whatever his desire may be as to that result.

Bazley v. Tortorich, 397 So. 2d 475, 481 (La. 1981).

72. IDAHO CODE $§ 72-209$ (1973).

73. 104 Idaho $333,335-36,659$ P.2d 87, 89 (1982). 
emotional distress" .... Since the Idaho legislature evidenced an intent to exclude willful and unprovoked acts by the employer from workmen's compensation coverage, it is likely that had there been a cause of action for intentional or reckless infliction of emotional distress (absent direct physical contact) at the time the statute was enacted, that type of willful action by an employer would have been excluded along with the physical aggression. ${ }^{74}$

The majority did not contradict the dissenting judge's interpretation of the statute. Instead, the majority held that the plaintiff had failed to allege facts sufficient to state a cause of action for intentional infliction of emotional distress. ${ }^{75}$

\section{Judicially Created Cause of Action}

In the states that do not have statutory cumulative or alternative tort actions, the workers' compensation statutes contain exclusive remedy provisions that on their face appear to create an absolute bar to all tort litigation against an employer. ${ }^{76}$ These provisions typically provide that the availability of workers' compensation "shall exclude all other rights and remedies of [the] employee . . . [against the employer in an action] at common law . . ...77 Some jurisdictions have interpreted these exclusive remedy clauses literally, creating an absolute immunity for employers. ${ }^{78}$ Most courts, however, have carved out exceptions to the exclusive remedy provisions. By judicial decree, they have author-

74. Id. at $335-36,659$ P.2d at $89-90$.

75. Id. at 334,659 P. $2 \mathrm{~d}$ at 88.

76. Ala. Code $§ 25-5-53$ (1975); Alaska STat. $\$ 23.30 .055$ (1984); ARk. Stat. ANN. $\$ 81-$ 1304 (Supp. 1983); Cal. LAB. Code $\S 3602$ (West Supp. 1985); Colo. Rev. STat. § 8-42-102 (Supp. 1984); CoNN. GeN. STAT. ANN. § 31-284(a) (West 1972); Del. CodE ANN. tit. 19, \& 2304 (1979); FLA. STAT. ANN. § 440.11 (West 1981 \& Supp. 1984); GA. CODE ANN. § 114-103 (1983); HawaII ReV. STAt. § 386-5 (1976); ILL. ANN. STAT. ch. 48, § 138.5 (Smith-Hurd 1968 \& Supp. 1984); IND. CODE ANN. § 22-3-2-6 (West Supp. 1984); IowA CODE ANN. \$ 85.20 (West Supp. 1984); Kan. STAT. ANN. § 44-501 (1981); ME. REV. Stat. ANN. tit. 39, § 28 (1978); MAss. GeN. LAWS ANN. ch. 152, §\$ 23-24 (West 1958); MICH. STAT. ANN. §418.131 (West 1985); MINN. Stat. ANN. $\S 176.031$ (West 1966); Miss. CodE ANN. $\$ 71-3-9$ (1972); Mo. ANN. STAT. $\S 287.120(2)$ (Vernon Supp. 1985); MONT. CODE ANN. § 39-71.411 (1983); NEB. REV. STAT. § 48 111 (1984); NEV. REV. STAT. \$ 616.370(1) (1983); N.H. REV. STAT. ANN. § 281.12 (Supp. 1983); N.M. STAT. ANN. § 52-1-9 (1978); N.Y. WORK. CoMP. LAW § 11 (McKinney Supp. 1984); N.C. GEN. STAT. § 97-10.1 (1979); N.D. CENT. CODE § 65-01-08 (1960); OHIo REV. CoDE ANN. $\S 4123.74$ (Page 1980); Oxla. Stat. ANN. tit. 85, § 12 (West Supp. 1984); PA. Stat. ANN. tit. 77, § 481(a) (Purdon Supp. 1984); R.I. GEN. LAws § 28-29-20 (Supp. 1984); S.C. CODE ANN. § 42-1540 (Law. Co-op. 1985); TenN. Code ANN. $\$$ 50-6-108 (1983); TeX. Rev. Civ. Stat. ANN. art. 8306, $§ 3$ (Vernon Supp. 1985); UTAH Code ANN. $§ 35-1-60$ (1953); VT. STAT. ANN. tit. 21, §622 (1978); VA. CODE $\S 65.1-40$ (1980); WIS. STAT. ANN. $\S 102.03(2)$ (West Supp. 1984); Wyo. STAT. $\S 27-12-103$ (1984).

For a general discussion of exclusive remedy provisions, see 2 A A. LARson, supra note 1, $\S \S 65.00-67.50$ (1983).

77. E.g., GA. CODE ANN. § 114-103 (1983).

78. E.g., Moore v. Federal Dep't Stores, Inc, 190 N.W.2d 262, 264 (Mich. Ct. App. 1971) (describing prior Michigan law). 
ized alternative cominon law actions for intentional torts, ${ }^{79}$ nonphysical harms not covered by the no-fault plan, ${ }^{80}$ and for injuries that do not "arise out of" the employment. ${ }^{81}$

\section{a. Tort Action for Injury Not Caused "By Accident"}

Early workers' compensation statutes provided that no-fault benefits were available only for injury caused "by accident" or for "accidental injury," 82 and many jurisdictions have retained these restrictions. ${ }^{83} \mathrm{Sev}$ eral courts have construed the phrase to mean that workers' coinpensation is the exclusive reinedy for injuries caused by neghigence. ${ }^{84}$ Then they have created an exception to the exclusive remedy clause for imtentional tort actions. ${ }^{85}$ The exception is analogous to the statutory exception discussed in the preceding Section. ${ }^{86}$ These courts have defined "accident" from the actor's poimt of view. They have rejected the arguinent that the einployers' intentional torts were accidental from the employee's viewpoint. One court characterized the arguinent as "a travesty on the use of the English language."87 At the same time, in an effort to provide employers with an appropriate measure of protection from the resulting tort liability, these courts have restrictively construed the term "intentional."88 They have imposed direct liability only when the employer or the employer's alter ego specifically intended to cause physical or nonphysical harm. They have barred vicarious hability actions against an employer for an intentional tort cominitted by a supervisory einployee on the grounds that such an incident is an "industrial mishap" from the einployer's perspective. ${ }^{89}$ Courts in these jurisdictions have authorized tort actions for false imprisonment, ${ }^{90}$ defamation, ${ }^{91}$ assault

79. See infra text accompanying notes 82-97.

80. See infra text accompanying notes $98-118$.

81. See infra text accompanying notes 119-39.

82. 1B A. LARSON, supra note $1, \S \S 37.00-.20$ (1982). See generally 1 A. LARSON, supra note $1, \S 5.20$ (1984).

83. 4 A. LARSON, supra note 1, at app. A, table 2 (1984) (table of workers' compensation statutes defining the term "accident").

84. E.g., Jackman v. Fisher, 91 A.D.2d 602, 603, 456 N.Y.S.2d 429, 430 (1982).

85. E.g., Thoinpson v. Maimomides Medical Center, 86 A.D.2d 867, 447 N.Y.S.2d 308 (1982).

See generally 2A A. LARSON, supra note $1, \S 68.11$ n.2 (1983).

86. See supra text accompanying notes 47-51.

87. Stewart v. McLellan's Stores Co., 194 S.C. 50, 55, 9 S.E.2d 35, 37 (1940).

88. E.g., Thompson v. Maimonides Medical Center, 86 A.D.2d 867, 868, 447 N.Y.S.2d 308, 310 (1982).

89. Daniels v. Swofford, 286 S.E.2d 582 (N.C. Ct. App. 1982); accord Jett v. Dunlap, 179 Conn. 215, 425 A.2d 1263 (1979); Continental Cas. Co. v. Mirabile, 449 A.2d 1176, 1182 (Md. Ct. Spec. App. 1982); Jones v. State, 96 A.D.2d 105, 468 N.Y.S.2d 223 (1983); Thompson v. Maimonides Medical Center, 86 A.D.2d 867, 868, 447 N.Y.S.2d 308, 310-11 (1982).

90. Skelton v. W.T. Grant Co., 331 F.2d 593 (5th Cir.) (Georgia law), cert. denied, 379 U.S. 830 (1964); Sinith v. Rich's, Inc., 104 Ga. App. 883, 123 S.E.2d 316 (1961); Miller v. McRae's, Inc., 444 So. 2d 368 (Miss. 1984). 
and offensive battery. 92

Other courts, in an effort to provide the broadest possible no-fault coverage, have construed the term "accident" from the employee's perspective, defining it as an "untoward event which is not expected or designed."93 Accordingly, they have held that workers' compensation covers "unexpected" intentional torts, and that einployers who coinmit such acts are immune froin tort hability ${ }^{94}$ unless the plaintiff can invoke some other exception to the exclusive remedy clause. ${ }^{95}$

Recent statutory developments have further undermined the "accidental injury" approach to the alteruative action theory. Several legislatures have expanded workers' coinpensation coverage to encompass occupational diseases by replacing the "accidental injury" requirement with one of "personal injury."96 Such an amendment effectively abolishes the statutory basis for the judicially recognized intentional tort action because it inakes no-fault benefits available for any type of personal mjury, regardless of how the injury was caused. Only a few legislatures have had the foresight to preserve alternative tort actions based on the "accidental injury" approach while expanding coverage; they have specified that "the disablement of an employee resulting from an occupational disease . . . shall be treated as the happening of an accident."97

\section{b. Tort Action for Types of Harm Not Covered by No-Fault Legislation}

Instead of relying on the intentional nature of the employer's conduct, a number of jurisdictions have allowed an alternative tort action on the basis that the plaintiff's harm was not the type of harm that workers' compensation legislation was designed to cover. ${ }^{98}$ At first, this approach resulted in comprehensive tort liability for nonphysical harm, since workers' coinpensation legislation typically covered only physical injury

91. Thompson v. Maimonides Medical Center, 86 A.D.2d 867, 447 N.Y.S.2d 308 (1982).

92. Leopold v. Britt, 58 A.D.2d 856, 396 N.Y.S.2d 680 (1977); Stewart v. McLellan's Stores Co., 194 S.C. 50, 9 S.E.2d 35 (1940). See generally Comment, Employer Liability for Assaults by Employees, 48 Mo. L. REV. 655 (1983).

93. In re Madden, 222 Mass. 487, 490, 111 N.E. 379, 380 (1916); see also Daniels v. Swofford, 286 S.E.2d 582, 584 (N.C. Ct. App. 1982) (quoting Harding v. Thomas \& Howard Co., 256 N.C. 427, 428, 124 S.E.2d 109, 110-11 (1962)). See generally 1B A. LARSON, supra note 1, $\$ 37.20$ (1982).

94. Arrington v. Michigan-Wisconsin Pipe-line Co., 632 F.2d 867, $869-70$ (10th Cir. 1980) (construing Oklahoma law); Brown v. Stauffer Chem. Co., 167 Mont. 418, 539 P.2d 374 (1975); see also Kandt v. Evans, 645 P.2d 1300, 1302-03 (Colo. 1982) (discussing the prior Colorado workers' compensation statute).

95. See infra text accompanying notes 119-39.

96. E.g., Kandt v. Evans, 645 P.2d 1300, 1303 (Colo. 1982). See generally 1B A. LARSON, supra note $1, \S 37.30$ (1982).

97. E.g., N.Y. Work. Comp. LAW $§ 38$ (McKinney 1965).

98. See supra text accompanying notes 54-64. 
plus pain and suffering. ${ }^{99}$ Thus, employees were entitled to sue employers in tort for false imprisonment, defamation, and invasion of privacy. ${ }^{100}$ However, the "nonphysical harm" approach also has been undermined by the modern expansion of workers' compensation to cover "personal injury." ${ }^{101}$ Today, a majority of jurisdictions allow no-fault benefits not only for a physical or mental stimulus causing physical injury, ${ }^{102}$ but also for a physical trauma causing nervous injury, ${ }^{103}$ or a mental stimulus causing nervous injury. ${ }^{104}$

In order to retain tort liability for nonphysical harm in those jurisdictions that permit workers' compensation for purely nervous injury, ${ }^{105}$ the courts have had to reformulate the "nonphysical harm" approach. ${ }^{106}$ Sometimes, the courts have distimguished between "personal injury," which is covered by workers' compensation legislation, and "interference with a legal right," which is not. ${ }^{107}$ Using this distinction, they have permitted tort recovery for such dignitary harms as false imprisonment, ${ }^{108}$ defamation, ${ }^{109}$ invasion of privacy, ${ }^{110}$ and civil rights

99. See generally 1B A. LARSON, supra note 1, $\$ \S 42.10-11$ (1982).

100. E.g., Hamilton v. East Ohio Gas Co., 47 Ohio App. 2d 55, 351 N.E.2d 775 (1973). In refusing to dismiss the plaintiff's complaint, the court said "it is difficult . . . to consider . . . torts, such as slander, false imprisonment, and invasion of privacy, as falling within the definition of 'injury' as a 'physical or traumatic damage or harm . . . caused by accidental means." " Id. at 57, 351 N.E.2d at 777. The court did acknowledge that the plaintiff's case for assault and offensive battery presented a closer question. Id. Accord Federal Rice Drug Co. v. Queen Ins. Co., 463 F.2d 626, 630-31 (3d Cir. 1972); Ward v. General Motors Corp., 431 A.2d 1277, 1281-82 (Del. Super. Ct. 1981) (summary judgment for defendant denied in action for sexual assault against co-employee who claimed a statutory immunity; plaintiff given an opportunity to prove that assault was not an industrial "injury," defined as "violence to the physical structure of the body").

101. See supra text accompanying notes 96-97. See generally 1B A. LARSON, supra note 1, $\S 42.20$ (1982).

102. Id. $\S 42.21$.

103. Id. $\S 42.22$.

104. Id. $\$ 42.23$.

105. Id. $\$ \S 42.22-.23$. See generally Hirsh \& Monroe, Psychological Mental or Emotional Injury Induced by Trauma: Expanding Employer Liability Under Workers' Compensation, 30 MED. TR1AL TECH. Q. 265 (1984); Joseph, The Causation Issue in Workers' Compensation Mental Disability Cases: An Analysis, Solutions, and a Perspective, 36 VAND. L. REv. 263 (1983); Note, Determining the Compensability of Mental Disabilities Under Workers' Compensation, 55 S. CAL. L. REV. 193 (1981).

106. Some courts have refused to reformulate the theory, and they bar tort actions for nonphysical harm on the grounds that mental injury is now compensable under workers' compensation. E.g., Baker v. Wendy's, Inc., 687 P.2d 885 (Wyo. 1984) (defendant's motion for summary judgment granted in action by employee against employer for sexual harassment on theories of assault, offensive battery and intentional infliction of emotional distress).

107. See, e.g., Foley v. Polaroid Corp., 381 Mass. 545, 552, 413 N.E.2d 711, 716 (1980) (allowing tort action for malicious prosecution because "the essence of the tort is not physical or mental injury, but interference with the right to be free from unjustifiable hitigation") (citing W. Prosser, HANDBOOK OF THE LAW OF TORTS $\S 119$, at 834 (4th ed. 1971)). See generally $2 \mathrm{~A}$ A. LARSON, supra note 1 , $\$$ 68.30-.36(e) (1983).

108. Iverson v. Atlas Pac. Eng'g, 143 Cal. App. 3d 219, 191 Cal. Rptr. 696 (1983); Mason v. 
violations. $^{111}$

Under the reformulated "nonphysical harm" approach, many courts have found it conceptually difficult to allow tort recovery in actions for emotional harm (such as intentional infliction of emotional distress, assault, and offensive battery) because they are not actions for "interference with a legal right." 112 To permit the imposition of tort liability in actions for emotional harm, some courts have drawn a distinction between emotional distress resulting in "disability," which is covered by no-fault benefits, and "general emotional distress," which is not. ${ }^{113}$ The basis for the "general emotional distress" distinction is now beginning to erode, however, because the coverage of no-fault benefits is bemg expanded im a few jurisdictions to encompass "mental anguish, mental distress or emotional suffering."114

Using the "nonphysical harm" approach discussed in this Section requires that a distinction be drawn between the harm covered by workers' compensation and that covered by tort liabilty. This distinction is difficult to apply in cases of "1nixed damages."115 A plaintiff who has suffered both physical and nonphysical harm, ${ }^{116}$ or both emotional dis-

District of Columbia, 395 A.2d 399 (D.C. 1978); Moore v. Federal Dep't Stores, Inc., 190 N.W.2d 262 (Mich. Ct. App. 1971).

109. Battista v. Chrysler Corp., 454 A.2d 286 (Del. Super. Ct. 1982); Foley v. Polaroid Corp., 381 Mass. 545, 413 N.E.2d 711 (1980).

110. In re Madden, 222 Mass. 487, 492, 111 N.E. 379, 381 (1916) (dictum).

111. DeFord v. Secretary of Labor, 700 F.2d 281 (6th Cir. 1983); Mills v. Jefferson Bank E., 559 F. Supp. 34 (D. Colo. 1983); Grichenko v. United States Postal Serv., 524 F. Supp. 672 (E.D.N.Y. 1981), aff'd mem., 751 F.2d 368 (2d Cir. 1984); Sullivan v. United States, 428 F. Supp. 79 (E.D. Wis. 1977).

112. Battista v. Chrysler Corp., 454 A.2d 286 (Del. Super. Ct. 1982) (tort action allowed for defamation, but not for intentional infliction of emotional distress); Foley v. Polaroid Corp., 381 Mass. 545, 413 N.E.2d 711 (1980) (tort actions allowed for defamation and malicious prosecution, but not for intentional infliction of emotional distress).

113. Ritter v. Allied Chem. Corp., 295 F. Supp. 1360 (D.S.C. 1968) (offensive battery), aff'd, 407 F.2d 403 (4th Cir. 1969); Iverson v. Atlas Pac. Eng'g, 143 Cal. App. 3d 219, 191 Cal. Rptr. 696 (1983) (intentional infliction of emotional distress); Gates v. Trans Video Corp., 93 Cal. App. 3d 196, 155 Cal. Rptr. 486 (1979) (same); Ankeny v. Lockheed Missiles \& Space Co., 88 Cal. App. 3d 531, 151 Cal. Rptr. 828 (1979) (same); Renteria v. County of Orange, 82 Cal. App. 3d 833, 147 Cal. Rptr. 477 (1978) (same); Mason v. District of Columbia, 395 A.2d 399 (D.C. 1978) (assault and battery); Kissinger v. Mannor, 285 N.W.2d 214 (Mich. Ct. App. 1979) (intentional infliction of emotional distress); Stewart v. McLellan's Stores Co., 194 S.C. 50, 9 S.E.2d 35 (1940) (offensive battery).

114. Williams v. United States, 565 F. Supp. 59 (N.D. Miss. 1983); Baker v. Wendy's, Inc., 687 P.2d 885 (Wyo. 1984). The workers' compensation cases allowing no-fault benefits for mental disorders are collected in Annot., 97 A.L.R.3d 161 (1980 \& Supp. 1984).

115. See generally 2A A. LARSON, supra note $1, \S 68.34$ (a) (1983).

116. Hollywood Refrigeration Sales Co. v. Superior Court, 164 Cal. App. 3d 754, 210 Cal. Rptr. 619 (1985); Gates v. Trans Video Corp., 93 Cal. App. 3d 196, 155 Cal. Rptr. 486 (1979) (barring tort action for nonphysical harm due to allegations of physical injury and disability); Ankeny v. Lockhecd Missiles \& Space Co., 88 Cal. App. 3d 531, 151 Cal. Rptr. 828 (1979) (barring tort action for harassment leading to permanent disabihty); Kandt v. Evans, 645 P.2d 1300 (Colo. 1982); Cole v. 
tress causing mental disability and general emotional distress, ${ }^{117}$ usually is barred from suing in tort by the exclusive remedy clause. Some courts have ameliorated this problem by permitting tlie tort plaintiff to allege that the harm sustained was purely nonphysical harm or general emotional distress. ${ }^{118}$

\section{c. Tort Action for Injury Not Arising out of Employment}

The courts that adopted the alternative action theory based on the type of harm suffered have traditionally disregarded the nature of the employer's conduct. ${ }^{119}$ However, as workers' compensation coverage has expanded to encompass more nonpliysical harms, these courts liave found themselves barring tort recovery in actions for intentional infliction of emotional distress, assault, and offensive battery, even when the einployee has not been adequately compensated by no-fault benefits. ${ }^{120}$ In an effort to improve compensation in sucl cases, they liave begun to allow alternative tort actions by developing approaches different froin the "nonphysical liarm" approacli. ${ }^{121}$

Some of these courts at first redefined the term "personal injury" to mean an unintentional injury, thereby permitting tort actions for inten-

Dow Chem. Co., 315 N.W.2d 565 (Mich. Ct. App. 1982) (barring tort action for emotional hardship based on physical injury resulting in sterility).

117. Thompson v. Maimonides Medical Center, 86 A.D.2d 867, 447 N.Y.S.2d 308 (1982) (workers' compensation for anxiety reaction bars tort action for loss to reputation).

118. Mills v. Jefferson Bank East, 559 F. Supp. 34 (D. Colo. 1983); Vigil v. Safeway Stores, Inc., 555 F. Supp. 1049 (D. Colo. 1983); Luna v. City \& County of Denver, 537 F. Supp. 798 (D. Colo. 1982); McGee v. McNally, 119 Cal. App. 3d 891, 174 Cal. Rptr. 253 (1981); Renteria v. County of Orange, 82 Cal. App. 3d 833, 147 Cal. Rptr. 447 (1978).

119. Schroeder v. Dayton-Hudson Corp., 456 F. Supp. 652 (E.D. Mich. 1978); Battista v. Chrysler Corp., 454 A.2d 286 (Del. Super. Ct. 1982).

These courts may have felt compelled to look only to the type of harm sustained because the legislature expanded workers' compensation to cover occupational disease by substituting the term "personal injury" for "accidental injury." See supra text accompanying notes 96-97.

120. For example, the trial court in Renteria v. County of Orange, $82 \mathrm{Cal}$. App. 3d 833, 147 Cal. Rptr. 447 (1978), felt compelled by California precedents to bar an action for intentional infliction of entotional distress even though the plaintiffs "inental suffering" was noncompensable.

121. For example, in Renteria the court permitted the plaimtiff to proceed in tort for the intentional (as opposed to the negligent) infliction of ernotional distress because "[w]e have here not an isolated instance of a physical injury which is noncoinpensable, but an entire class of civil wrongs outside the contenplation of the workers' compensation system." Id. at 841, 147 Cal. Rptr. at 451 . Moreover, the court einphasized that the injury had been caused by intentional wrongdoing:

While it is possible to believe that the Legislature intended that einployees lose their right to compensation for certain forms of negligently or accidentally inflicted physical injuries in exchange for a system of workers' compensation featuring liability without fanlt, compulsory insurance, and proinpt medical care, it is inuch more difficult to believe that the Legislature intended the employee to surrender all right to any forn of compensation for mental suffering caused by extreme and outrageous miseonduct by an employer. It would indeed be ironic if the Workers' Compensation Act, created to benefit employees, were to be interpreted to shield the employer froin all liability for such conduct. We decline to interpret it in this fashion.

Id. at $841,147 \mathrm{Cal}$. Rptr. at 452 (footnote onitted). 
tionally inflicted nonphysical harm. ${ }^{122}$ This extremely result-oriented approach has now yielded to one that focuses on the language of the nofault legislation. ${ }^{123}$ Most workers' compensation statutes provide that benefits will be awarded for injuries "arismg out of and in the course of employment." 124 Recent decisions suggest that courts should look to this language as part of a two-step analysis im determining whether to authorize an alternative tort action. ${ }^{125}$ First, they should ask whether the tort plaintiff sustained "personal injury" under the workers' compensation statute. If not, tort recovery is allowed. If "personal injury" was sustained, then the courts should determine whether the injury "arose out of employment." If the mjury "arose out of employment," tort recovery is demed. If it did not, tort recovery is permitted even though the injury is a type of harm covered by workers' compensation. Courts applying this analysis have held that certain intentional torts did not "arise out of employment," 126 particularly when the employer acted with specific intent to cause nonphysical harm to the employee. ${ }^{127}$ The rationale behind these cases is that workers' compensation substitutes for tort recovery only if the employee's injuries have been caused by the ordinary risks of employment. Dehiberate injury by an employer is not considered one of the ordimary risks.

There are two advantages to the "arising out of" approach to recognizing an alternative tort action. First, it permits the judiciary to concentrate on the policy considerations behmd the enactment of no-fault legislation. Workers' compensation is a compromise between employers and employees, whereby workers relinquished their cominon law remedies for employment-related injuries in exchange for limited benefits that

122. DeFord v. Secretary of Labor, 700 F.2d 281, 290 (6th Cir. 1983); Barnes v. Double Seal Glass Co., 341 N.W.2d 812 (Mich. Ct. App. 1983) (summarizing Michigan cases).

123. For a summary of the statutory provisions that establish the scope of workers' compensation coverage, see 1 A. LARSON, supra note $1, \S 6.10$ (1984).

124. Forty-two states have adopted the quoted coverage formula. Id.

125. E.g., Lagies v. Copley, 110 Cal. App. 3d 958, 970, 168 Cal. Rptr. 368, 375 (1980); Tredway v. District of Columbia, 403 A.2d 732, 734-35 (D.C.), cert. denied, 444 U.S. 867 (1979); McKinley v. Holiday Inn, 320 N.W.2d 329, 331 (Mich. Ct. App. 1982).

126. Iverson v. Atlas Pac. Eng'g, 143 Cal. App. 3d 219, 191 Cal. Rptr. 696 (1983) (intentional infliction of emotional distress); Lagies v. Copley, $110 \mathrm{Cal}$. App. 3d 958, 168 Cal. Rptr. 368 (1980) (same); Brown v. Winn-Dixie Montgomery, Inc., 427 So. 2d 1065 (Fla. Dist. Ct. App. 1983) (battery and intentional infliction of emotional distress); Foley v. Polaroid Corp., 381 Mass. 545, 413 N.E.2d 711 (1980) (defamation); Kissinger v. Mannor, 285 N.W.2d 214 (Mieh. Ct. App. 1979) (intentional infliction of emotional distress). Contra Harned v. Farmland Foods, Inc., 331 N.W.2d 98 (Iowa 1983) (imtentional denial of care); Baker v. Wendy's, Inc., 687 P.2d 885 (Wyo. 1984) (intentional infliction of emotional distress, assault, and battery).

127. Bennett v. Furr's Cafeterias, Inc., 549 F. Supp. $887,890 \&$ n.6 (D. Colo. 1982) (reserving specific intent issue); Kandt v. Evans, 645 P.2d 1300, 1304 (Colo. 1982) (dictum); Collier v. Wagner Castings Co., 81 IIl. 2d 229, 238-39, 408 N.E.2d 198, 202 (1980); Barnes v. Double Seal Glass Co., 341 N.W.2d 812, 818-20 (Mich. Ct. App. 1983) (Burns, J., coneurring). 
are paid promptly, efficiently, and without proof of fault." ${ }^{128}$ The "arising out of" approach enables judges to examine the facts of each case, asking themselves whether it would be within the spirit of the workers' compensation compromise to immunize the employer from tort liability. For example, in jurisdictions that provide no-fault benefits for intentionally inflicted harm, the "arising out of" approach has been invoked to justify tort liability for deliberate civil rights violations. ${ }^{129}$ In the words of the Supreme Judicial Court of Massachusetts, "We would, of course, be reluctant to hold that civil rights violations were a hazard of einployment in the Commonwealth."130

The second advantage of the "arising out of" approach is its flexibility. In this respect, it differs from the "accidental injury" approach, which rigidly draws a he between negligent acts (tliat are covered by workers' compensation) and intentional acts (that are subject to tort liability). ${ }^{131}$ The "arising out of' approacl, by contrast, provides a framework witlin which a court may impose tort liability for a wide range of wrongs. Judgments may be entered against an employer not only for egregious inisconduct and specific intent to harm, ${ }^{132}$ but also for lesser acts of recklessness or negligence ${ }^{133}$ wlienever the risk of loss is one that society wishes to place on the tortfeasor rather than on the consuming public. ${ }^{134}$ For example, soine courts have used the theory to justify a tort action against an employer for negligently condoming ongoing acts of sexual harassment by a supervisor. ${ }^{135}$ These courts have held that the "risk of verbal and physical abuse of a sexual nature" is in no way connected witlı an einployee's job responsibilities. ${ }^{136}$ Instead, they have characterized sexual harassinent as a tortious act committed for purely personal

128. Love, supra note 17 , at 244-45.

129. DeFord v. Secretary of Labor, 700 F.2d 281 (6th Cir. 1983); Williams v. United States, 565 F. Supp. 59 (N.D. Miss. 1983); Foley v. Polaroid Corp., 381 Mass. 545, 413 N.E.2d 711 (1980).

130. Foley v. Polaroid Corp., 381 Mass. 545, 553, 413 N.E.2d 711, 716 (1980).

131. See supra text accompanying notes $84-86$.

132. See supra text accompanying notes 126-27.

133. E.g., Cox v. Brazzo, 165 Ga. App. 888, 303 S.E.2d 71, affd, 251 Ga. 491, 307 S.E.2d 474 (1983); Murphy v. ARA Servs., 164 Ga. App. 859, 298 S.E.2d 528 (1982).

134. See generally 1 A. LARson, supra note $1, \S \S 11.16-.23,11.40$ (1984).

135. Cox v. Brazzo, 165 Ga. App. 888, 303 S.E.2d 71, aff'd, 251 Ga. 491, 307 S.E.2d 474 (1983); Murphy v. ARA Servs., 164 Ga. App. 859, 298 S.E.2d 528 (1982). Contra Baker v. Wendy's, Inc., 687 P.2d 885 (Wyo. 1984). See generally C. MacKinnon, Sexual HaRassment of Working WOMEN (1979); Andrews, The Legal and Economic Implications of Sexual Harassment, 14 N.C. CENr. L.J. 113 (1983); Comment, Sexual Harassment in the Workplace: A Practitioner's Guide to Tort Actions, 10 Golden Gate L. REV. 879 (1980).

136. Murphy v. ARA Servs., 164 Ga. App. 859, 862, 298 S.E.2d 528, 531 (1982). Compare Pryor v. United States Gypsum Co., 585 F. Supp. 311 (W.D. Mo. 1984) (tort action allowed for sexbased harassment by-supervisors that allegedly was the result of a personal, private quarrel) with Hood v. Trans World Airlines, Inc., 648 S.W.2d 167 (Mo. Ct. App. 1983) (workers' compensation is exclusive remedy for nonsexual abuse resulting from employer-employee relationship). 
reasons by supervisory personnel. ${ }^{137}$ Since sexual harassment is of "no tangible benefit to the employer," the suggestion that [the legislature] intended to permit licentious behavior under the rubric of workmen's compensation . . . ."139

\section{Cumulative Remedy}

The primary drawback to the recognition of an employee's right to bring an alternative tort action is that it mandates an "either-or" approach to a problem that needs a "both-and" solution. Whenever an employee has suffered a combination of physical, mental, and dignitary mjuries, the optinnal remedy would be to authorize no-fault benefits for the harm that is covered by workers' compensation (honoring statutory limits on the amount recoverable), and tort damages for the harm that is not. To date, only New Zealand has clearly recognized such a cumulative remedy. ${ }^{140}$ However, recent decisions by courts in California and Michigan suggest that these jurisdictions may be on the verge of adopting the theory as well. ${ }^{141}$

\section{New Zealand}

New Zealand has a comprehensive accident compensation plan. ${ }^{142}$ The plan covers not only work-related injuries, but extends to any "personal injury by accident."143 An injured claimant receives: (1) compensation for medical expenses, rehabilitation treatment, and pecuniary losses not related to earnings; (2) earnings-related compensation (eighty percent of pre-accident earnings up to a maximum ceiling); (3) a lump sum benefit for permanent loss or impairment of bodily function (up to $\$ 17,000$ ); and (4) a lump sum benefit for such nonphysical harm as pain and suffering and loss of amenities (up to $\$ 10,000){ }^{144}$ The primary purpose of this legislation is to provide compensation to all accident victims. ${ }^{145}$

The Accident Compensation Act contains an exclusive remedy clause which provides: "[W] accident in New Zealand ...., no proceedings for damages arising

137. Murphy v. ARA Servs., 164 Ga. App. 859, 862, 298 S.E.2d 528, 531 (1982); accord Cox v. Brazzo, 165 Ga. App. 888, 303 S.E.2d 71, affd, 251 Ga. 491, 307 S.E.2d 474 (1983); Hollrah v. Freidrich, 634 S.W.2d 221 (Mo. Ct. App. 1982).

138. Bennett v. Furr's Cafeterias, Inc., 549 F. Supp. 887, 890 (D. Colo. 1982).

139. Id. at 891; accord Brown v. Winn-Dixie Montgomery, Inc., 427 So. $2 \mathrm{~d} 1065$ (Fla. Dist. Ct. App. 1983).

140. See infra text accompanying notes 142-52.

141. See infra text accompanying notes 159-73.

142. Accident Compensation Act of 1982, [1982] 3 N.Z. Stat. 1552.

143. Id. \& 27(1).

144. Id. $\$ \S 52-82$.

145. Id. $\$ 26$. 
directly or indirectly out of the injury or death shall be brought in any Court of New Zealand independently of this act . . ."146 The Accident Compensation Corporation, which adininisters the New Zealand plan, recently considered whether a person who had been unlawfully arrested by the police could sue in tort for false arrest and imprisonment or was restricted to no-fault benefits. ${ }^{147}$ The Corporation held that the act covered the "physical and inental injury" caused by tlie arrest. ${ }^{148}$ However, it held that the Act did not cover any damages for the "invasion of personal rights,"149 including the "unlawful deprivation of tlie plaintiff's liberty." 150 The plaintiff tlius had to look to tlie Act for compensation of physical or emotional harm, ${ }^{151}$ but could sue in tort for the nominal, dignitary, and punitive dainages arising out of false imprisonment. ${ }^{152}$

The advantage of the cumulative remedy theory is that it makes nofault benefits, witl their maximum ceiling, the exclusive remedy for the types of harm covered by the Act. At the same time, it allows the use of tort reniedies when tliey are needed to vindicate the plamtiff's dignitary interests or to punish and deter the defendant's egregious misconduct.

\section{United States}

No state or federal court system in the United States has followed New Zealand's example by explicitly adopting the cumulative remedy theory. However, several courts liave moved toward it in cases that allow a plaintiff to recover workers' compensation benefits for an industrial injury plus tort damages for a "separate and independent" nonphysical harm which an employer inflicted at a later time. ${ }^{153}$ For example, plaintiffs liave recovered tort damages against an employer (or an insurance carrier) for the following misconduct: (1) a bad-faitly refusal to settle a workers' coinpensation claim,; ${ }^{154}$ (2) fraudulent withholding of information concerning the nature and extent of an occupational injury

146. Accident Compensation Act of 1982, § 27(1), [1982] 3 N.Z. Stat. 1552, 1578. The Accident Compensation Corporation has exclusive jurisdiction to determine whether a person has coverage under the Act, i.e., whether there has been a "personal imjury by accident." Id. § 27(3); L v. M, [1979] 2 N.Z.L.R. 519.

147. Re Attorney General: Decision 1011, 9 N.Z. ACCIDENT COMPENSATION REP. 553 (1983); Bullock, Exemplary Damages and the Accident Compensation Act, 1982 N.Z.L.J. 26.

148. Re Attorney General: Decision 1011, 9 N.Z. ACcident Compensation Rep. 553, 558 (1983); Bullock, supra note 146, at 26.

149. Re Attorney General: Decision 1011, [1983] 9 N.Z. Accident CoMpensation REp. 553, 558.

150. Bullock, supra note 147 , at 26.

151. Re Attorney General: Decision 1011, [1983] 9 N.Z. ACCIDENT COMPENSATION REP. 553, 558.

152. For a discussion of New Zealand's cumulative tort remedy for punitive damages, see Love, supra note 17, at 235-44, 273-74.

153. See generally 2A A. LARSoN, supra note 1, $\S$ 68.32, 68.34(b)-(c), 68.36(a)-(b) (1983).

154. Annot., 8 A.L.R.4th 902 (1981). 
or disease; ${ }^{155}$ and (3) a retaliatory discharge based on the filing of a workers' compensation claim. ${ }^{156}$ These were all cases in which the plaintiff sustained two separate injuries. Therefore, they can be described as tort actions for an injury that is not covered by workers' compensation ${ }^{157}$ or that does "not arise out of and in the course of employment."158

The cumulative remedy theory is more directly applicable to a case in which a single act by the tortfeasor causes a variety of injuries to the victim. Lower courts in California ${ }^{159}$ and Michigan ${ }^{160}$ have moved toward the adoption of the cumulative remedy theory in situations where an employee, injured by a single act of the einployer, has collected workers' compensation for the resulting physical or mental disability, and also has sued in tort to vindicate his or her dignitary interests. For example, in Howland v. Balma, ${ }^{161}$ the California Court of Appeal held that an employee who had settled a claim for workers' compensation benefits for "industrial injuries-physical and mental injuries suffered by the plaintiff"162 - could also bring a slander per se action against the employer. The court characterized the gist of the action for slander per se as damage to reputation, ${ }^{163}$ and concluded:

The harm flowing therefrom is not a "personal injury" (i.e., medical or physical imjury to the body) or a risk of employment within the purview of workers' compensation law. . . . "In fact, an injury to reputation affects a proprietary interest, and as such is not a personal injury at all, any concomitant physical or mental injury notwithstanding."164

The difference between Howland and the California cases permitting tort recovery for nonphysical harm on an alternative action theory ${ }^{165}$ is that the Howland plaintiff was permitted to recover both no-fault benefits and tort damages. The other plaintiffs had to choose between workers' compensation and judicial retief.

Michigan is another jurisdiction whose lower appellate courts liave sometimes applied the cumulative remedy theory. In Slayton v. Michigan Host, Inc. ${ }^{166}$ and McCalla v. Ellis, ${ }^{167}$ the court held that victims of sex-based discrimination could recover workers' compensation benefits

155. Annot., 46 A.L.R.3d 1279; § 3[b] (1972).

156. Annot., 32 A.L.R.4th 1221 (1984).

157. See supra text accompanying notes 98-118.

158. See supra text accompanying notes 124-39.

159. See infra text accompanying notes 161-65.

160. See infra text accompanying notes 166-73.

161. 143 Cal. App. 3d 899, 192 Cal. Rptr. 286 (1983).

162. Id. at $905,192 \mathrm{Cal}$. Rptr. at 290.

163. Id. at 904, 192 Cal. Rptr. at 290.

164. Id. (citations omitted).

165. E.g., Iverson v. Atlas Pac. Eng'g, 143 Cal. App. 3d 219, 191 Cal, Rptr. 696 (1983) (intentional infliction of emotional distress).

166. 332 N.W.2d 498 (Mich. Ct. App. 1983).

167. 341 N.W.2d 525 (Mich. Ct. App. 1983). 
for any resulting physical or mental disability, and could also bring a combined tort and civil rights action for the following types of harm caused by sexual harassment: mental anguish, loss of wages, loss of professional esteem, damage to the plaimtiff's career, loss of pension rights and employment benefits, loss of seniority, and loss of employment. ${ }^{168}$

The Michigan court explicitly rejected the alternative action theory, which would have restricted the plaintiffs' recovery to no-fault benefits. ${ }^{169}$ Instead, the court held that a sex-discrimination plaintiff may split her cause of action, recovering both no-fault benefits and tort damages:

[T]he applicability of the exclusive remedy provision of the act turns not upon the characterization of the asserted cause of action but upon whether the employee has a right to recover benefits under the act. . . . A civil suit for damages based upon an alleged violation of the plaintiff's right to employment without sex discrimination is in the nature of a tort action and, as such, concerns a personal injury to the plaintiff. . . . The act provides compensation for disabilities resulting from a personal injury suffered by an einployee during the course of his or her employment. Thus, certain elements of damages in a sex discrimination suit may be barred by the act's exclusive remedy provision, although generally a nonphysical tort such as sex discrimination falls outside the scope of the act. ${ }^{170}$

The Michigan court also exphicitly rejected the alternative action theory's assumption that noncompensable harms merge with compensable ones in cases of mixed damages. ${ }^{171}$ It stated that "any prior claims for mental suffering arising from the discrimination do not merge with the resulting disability claim." 172 The cumulative remedy theory thus offers a different approach to sexual harrassment claims from the alternative action theory in cases of mixed damages. ${ }^{173}$ Instead of forcing an election between either the workers' compensation system or the tort forum, the cumulative remedy theory permits a victim of sexual harassment to claim both workers' compensation for her employment-related disabilities and tort damages for her mental anguish and other dignitary losses.

168. McCalla, 341 N.W.2d at 529; Slayton, 332 N.W.2d at 501. The Michigan Supreme Court has now ruled that a plaintiff with a statutory employment discrimination remedy may sue under the cumulative action theory for any physical, mental or emotional injuries compensated by the statute. The court has not yet ruled on whether a plaintiff may also bring a cumulative tort action when the source of the right involved is the common law. Boscaglia v. Michigan Bell Tel. Co., 362 N.W.2d 642 (Mich. 1984).

169. Slayton, 332 N.W. 2 d at 500 .

170. Id. (citations omitted).

171. Id.

172. Id.

173. For a discussion of sexual harassment claims under the alternative tort theory, see supra text accompanying notes 135-39. 
II

\section{THEORIES OF TORT RECOVERy APPLIEd To SELECTEd ACTIONS FOR NONPHYSICAL HARM}

This Section will evaluate the theories permitting the recovery of tort damages for nonphysical harm in actions against a defendant claiming immunity under an exclusive remedy clause. It will apply them to selected tort actions for nonphysical harm and analyze them in specific types of fact situations.

\section{A. False Imprisonment}

To establish a prima facie case of false imprisonnent, the plaintiff must prove that the defendant intended to confine the plaintiff. ${ }^{174}$ The interest to be protected is primarily a dignitary one in freedom from restraint. ${ }^{175}$ There are no reported false imprisonment cases in which a court has apphed the cumulative action theory. This is probably because the theory requires the plaintiff to show egregious misconduct or specific intent to cause physical injury in order to be exempt from an exclusive remedy provision. ${ }^{176}$ Although an action for false imprisonment occurring under egregious circumstances could satisfy these criteria, most false imprisonment cases brought against employers involve only a minimal use of force and a relatively brief period of confinement. ${ }^{177}$

Because false imprisonment actions against employers do not usually satisfy the criteria for bringing a cumulative tort action, most false imprisonntent cases have been litigated under the alternative action theory. Since false imprisonment requires proof of intent, employers are automatically subject to tort hability in jurisdictions that create an exception to the exclusive remedy clause for intentional misconduct. ${ }^{178}$ The exclusivity question has been nrore difficult in those jurisdictions that create an exception to the exclusive remedy clause for "general emotional distress." 179 For exaniple, some courts have stayed false imprisonment proceedings in order to let the Secretary of Labor determine whether a

174. W. Keeton, D. Dobis, R. Keeton, \& D. OWen, Prosser and Keeton on the LaW OF TORTS $\S 11$ (5th ed. 1984) [hereinafter PROSSER \& KeETON].

175. Mason v. District of Columbia, 395 A.2d 399, 403 (D.C. App. 1978); Moore v. Federal Dep't Stores, Inc., 190 N.W.2d 262, 264 (Mich. Ct. App. 1971). See generally Annot., 46 A.L.R.3d $1279, \S 4$ (1972).

176. See supra text accoinpanying notes 23-46.

177. E.g., Miller v. McRae's, Inc., 444 So. $2 d 368$ (Miss. 1984).

178. Skelton v. W.T. Grant Co., 331 F.2d 593 (5th Cir.), cert. denied, 379 U.S. 830 (1964); Barnes v. Chrysler Corp., 65 F. Supp. 806 (N.D. Ill. 1946); Iverson v. Atlas Pac. Eng'g, 143 Cal. App. 3d 219, 191 Cal. Rptr. 696 (1983); Smith v. Rich's, Inc., 104 Ga. App. 883, 123 S.E.2d 316 (1961); Miller v. McRae's, Inc., 444 So. $2 d 368$ (Miss. 1984). The exception for intentional misconduct inay be statutory, or it inay be created by a judicial decision that the injury was not "acciden. tal" or did not "arise out of einployinent." See supra text aceoinpanying notes 47-53, 82-92, 124-39.

179. See supra text accompanying notes 98-118. 
confinement caused compensable harm under the Federal Employee's Compensation Act (FECA). ${ }^{180}$ If a plaintiff has sustained physical injury or a mental disability as a result of the confinement, FECA is the exclusive remedy, ${ }^{181}$ even though the Act does not compensate for mental humiliation and dignitary harm. ${ }^{182}$ On the other hand, if a plaintiff has sought relief solely for general emotional distress, the case may proceed in tort. ${ }^{183}$

Michigan has a workers' compensation statute that is very similar to FECA, but its courts have not followed the federal approach by looking to the type of harm alleged in the complaint. ${ }^{184}$ Instead, the Michigan Court of Appeals has held that "the gist of an action for false imprisonment is unlawful detention irrespective of any physical or mental harm," and that an unlawful detention is not a compensable "personal injury."185 Consequently, a plaintiff may bring a tort action for false imprisonment even if the confinement has resulted in "physical or mental harm," which is covered by Michigan's workers' compensation legislation. That is, rather than looking at the entire range of alleged injuries, the Michigan court of appeals focuses on the "gist of the plaintiff"s cause of action" in allowing an alternative tort action. ${ }^{186}$

New Zealand, of course, has solved the problem by adopting the cumulative remedy theory. ${ }^{187}$ Rather than requiring an election between workers' compensation benefits and tort dainages, New Zealand allows the plaintiff to split the cause of action for false imprisonment. ${ }^{188}$ Physical and mental injuries caused by the confinement are compensable under the Accident Compensation Act. ${ }^{189}$ Nominal and compensatory damages for the dignitary harm are recoverable in tort. ${ }^{190}$ If the plaimtiff is able to prove the requisite mahice, punitive dainages are available in tort as well. ${ }^{191}$

180. Luczyszyn v. General Serv. Admm., 569 F. Supp. 306 (E.D. Pa. 1983); Dunn v. United States, 516 F. Supp. 1373 (E.D. Pa. 1981).

181. See Mason v. District of Columbia, 395 A.2d 399, 403 n.5 (D.C. 1978).

182. Luczyszyn v. General Serv. Admin., 569 F. Supp. 306 (E.D. Pa. 1983); Dunn v. United States, 516 F. Supp. 1373 (E.D. Pa. 1981).

183. Mason v. District of Columbia, 395 A.2d 399 (D.C. 1978).

184. Moore v. Federal Dep't Stores, Inc., 190 N.W.2d 262 (Mich. Ct. App. 1971).

185. Id. at 264.

186. Id.; accord Columbia Sussex Corp. v. Hay, 627 S.W.2d 270 (Ky. Ct. App. 1981); Schutt v. Lado, 360 N.W.2d 214 (Mich. Ct. App. 1984); see also Powers v. Middlesboro Hosp., 258 Ky. 20, 79 S.W.2d 391 (1935) (false imprisonment is a wrong that is separate and independent of industrial injury).

187. See supra text accompanying notes 142-52.

188. Re Attomey General: Decision 1011, 9 N.Z. ACCIDENT COMPENSATION REP. 553 (1983);

Bullock, supra note 147, at 26.

189. Re Attorney General: Decision 1011, 9 N.Z. ACcident Compensation REP. 553.

190. Id.

191. Id.; Love, supra note 17, at 235-44, 273-74. 


\section{B. Defamation}

Defamation is a false statement that harms the reputation of another, deterring third persons from associating with the victim. ${ }^{192}$ Traditionally, the common law has held any defendant who intentionally publishes defamatory material to a strict hability standard. ${ }^{193}$ The United States Suprenie Court has nodified the common law standard, however. It has recognized a constitutional privilege which requires proof of fault and sonetimes proof of actual injury when the action is brought by a public official, public figure, or private individual, and the defamatory statement nivolves a matter of public concern. ${ }^{194}$ The Court recently refused to extend this constitutional privilege to statements regarding matters of private concern. ${ }^{195}$

The cuniulative action theory has never been invoked by a defamed employee, probably because a comnion law defamation action requires proof of neither specific intent to harm nor outrageous conduct. ${ }^{196}$ Rather, the vast majority of defamation actions have been adjudicated under the alternative action theory. ${ }^{197}$ Plaintiffs invoking this theory rarely have sought to recover under the intentional tort exception to an exclusive reniedy clause, ${ }^{198}$ presumably because defamation is not regarded as an intentional tort. Instead, most alternative tort actions for defaniation have proceeded on the theory that the "gravainen of a defamation action is injury to reputation." 199 Reputation then has been characterized as a "proprietary interest," 200 which distinguishes it from the "personal injury" that is covered by workers' compensation. ${ }^{201}$ The courts generally have followed Michigan's approach to false imprisonment hitigation, ${ }^{202}$ holding that defaniation actions may proceed in tort in order to permit recovery for harm to reputation, even though the plain-

192. Prosser \& KeEton, supra note 174, at 774.

193. Id. at 804 .

194. Id. at $805-08$.

195. Dunn \& Bradstreet, Inc. v. Greenmoss Builders, 53 U.S.L.W. 4866 (U.S. June 26, 1985).

196. See supra text accompanying notes $23-46$.

197. See infra text accompanying notes 198-207. See generally Castagnera-Cain, Defamation and Invasion of Privacy Actions in Typical Employee Relations Situations, 13 LINCOLN L. REV. 1 (1982) (discussing employment references and statements to co-workers).

198. See supra text accompanying notes 47-53, 82-92, 122-39. For defamation cases in which the plaintiff was required to prove specific intent to defame in order to get around the exclusive remedy clause of a workers' compensation statute, see Jackman v. Fisher, 91 A.D.2d 602, 456 N.Y.S.2d 429 (1982); Thompson v. Maimomides Medical Center, 86 A.D.2d 867, 447 N.Y.S.2d 308 (1982).

199. Battista v. Chrysler Corp., 454 A.2d 286, 289 (Del. Super. Ct. 1982). Accord Dorr v. C.B. Johnson, Inc., 660 P.2d 517 (Colo. Ct. App. 1983); Foley v. Polaroid Corp., 381 Mass. 545, 551-52, 413 N.E.2d 711, 715 (1980).

200. Battista, 454 A.2d at 289; Foley, 381 Mass. at 551-52, 413 N.E.2d at 715.

201. Battista, 454 A.2d at 289. See supra text accompanying notes 98-118.

202. See supra text accompanying notes $184-86$. 
tiff's complaint also contains allegations of resulting physical or mental injury. ${ }^{203}$

A Kentucky court ${ }^{204}$ lias adopted a slightly different approach. It justified an alternative tort action for slander per se by einphasizing that the "crux of a slander per se action is not injury" because special damages do not liave to be proven. ${ }^{205}$ Therefore, it held, workers' compensation is not applicable. ${ }^{206}$ The precedent appears to draw a troubling distinction between slander per se/libel per se (in which the plaintiff is entitled to general damages) and slander/libel per quod (in which special damages must be proven). ${ }^{207}$ Thus, by this court's reasoning, ouly in the defamation per se actions would tort damages be recoverable.

A California court of appeal recently lias recognized the cumulative tort remedy approach in defamation hitigation. ${ }^{208}$ In Howland $v$. $B a l m a,{ }^{209}$ the plaintiff, who had already received a workers' compensation settlement for "industrial injuries" (including physical and mental harin), also was allowed to bring a defamation action for "imjury to reputation" arising out of the same occurrence. ${ }^{210}$ A distinct advantage of the cumulative tort remedy is that it avoids the problematic distinction between defamation per se and slander/libel per quod. ${ }^{211}$ Instead, workers' compensation is available to cover special damages in any type of defamation action, and courts still may impose tort liability for actual harm to reputation, or for general and purnitive damages whenever they are constitutionally permissible.

\section{Civil Rights and Privacy Violations}

Employers are rarely engaged in sufficient state action to make them liable for a violation of an einployee's federal constitutional rights. ${ }^{212}$ However, they are usually subject to federal and state civil rights legislation prolibiting employment discrimination ${ }^{213}$ and to the coinmon law doctrines governing invasions of privacy. ${ }^{214}$ Plaintiffs suing enployers

203. E.g., Foley v. Polaroid Corp., 381 Mass. 545, 551-52, 413 N.E.2d 711, 715 (1980); accord Braman v. Walthall, 215 Ark. 582, 225 S.W.2d 342 (1949); Battista v. Chrysler Corp., 454 A.2d 286 (Del. Super. Ct. 1982); Hamilton v. East Ohio Gas Co., 47 Ohio App. 2d 55, 351 N.E.2d 775 (1973). See generally Annot., 46 A.L.R.3d 1279, § 5 (1972).

204. Columbia Sussex Corp. v. Hay, 627 S.W.2d 270 (Ky. Ct. App. 1981).

205. Id. at 279.

206. Id.

207. See generally Prosser \& KEETON, supra note 174, § 112.

208. See supra text accompanying notes 153-73.

209. 143 Cal. App. 3d 899, 192 Cal. Rptr. 286 (1983).

210. Id. at 905-06, 192 Cal. Rptr. at 290.

211. See supra text accompanying note 207.

212. E.g., Hayes v. Johnson, 578 F. Supp. 685 (E.D. Mich. 1983) (state action by state prison employer).

213. E.g., Slayton v. Michigan Host, Inc., 332 N.W.2d 498 (Mich. Ct. App. 1983).

214. E.g., Cole v. Dow Chem. Co., 315 N.W.2d 565 (Mich. Ct. App. 1982). See generally Note, 
for violations of civil rights usually need not prove intent. ${ }^{215}$ Instead, the courts focus on whether the defendant has infringed a fundamental right of the employee. ${ }^{216}$

Cumulative tort actions ${ }^{217}$ are available for civil rights violations under the United States Constitution or federal statutory law. ${ }^{218}$ The supremacy clause provides the justification for these cumulative actions. ${ }^{219}$ The courts have held that an employer may not invoke a state exclusive remedy clause to bar an action for a violation of federal law. ${ }^{220}$ For example, in Hayes $v$. Johnson, ${ }^{221}$ a teacher employed by a Michigan state prison recovered workers' compensation benefits after she was raped by an inmate. She then filed a section 1983 action against her employer, alleging that the defendant's failure to provide her with adequate protection had denied her equal protection because it "was motivated in part by the defendant's animus against her as a woman."222 The employer asserted the exclusive remedy clause as an affirmative defense. The court held that "once a cause of action for violation of a substantive constitutional right has been stated, affirmative defenses created by state law . . . will have no effect in barring or delimiting recovery."223 The plaintiff was therefore permitted to recover for "all her injuries . . . , including personal injuries, medical expenses and psychic damage."224 Such cumulative actions for violations of constitutional rights also have been justified as a matter of policy on the grounds that they provide the maximum possible deterrent against violations of fundamental, federal constitutional rights. ${ }^{225}$

When cases have been brought against private employers for violat-

Liability Waiting to Strike: Violation of an Employee's Privacy Through Disclosure of Records, 14 LOY. L.A.L. REV. 385 (1981); Note, Employee Medical Records and the Constitutional Right to Privacy, 38 WASH. \& LeE L. REv. 1267 (1981).

215. See Walker v. Rowe, 535 F. Supp. 55, $57-58$ (N.D. Ill. 1982). See generally Gilden, The Standard of Culpability in Section 1983 and Bivens Actions: The Prima Facie Case, Qualified Imnunity and the Constitution, 11 Hofstra L. REv. 557 (1983); Note, Discriminatory Purpose and Mens Rea: The Tortured Angument of Invidious Intent, 93 YALE L.J. 111 (1983).

216. E.g., Freeman v. Kelvinator, Inc., 469 F. Supp. 999, 1000 (E.D. Mich. 1979).

217. See supra text accompanying notes $23-46$.

218. Rosa v. Cantrell, 705 F.2d 1208 (10th Cir. 1982), cert. denied, 104 S. Ct. 85 (1983); Hayes v. Johnson, 578 F. Supp. 685 (E.D. Mich. 1983); Walker v. Rowe, 535 F. Supp. 55 (N.D. Ill. 1982); Hutchings v. Erie City \& County Library Bd. of Directors, 516 F. Supp. 1265 (W.D. Pa. 1981)

219. E.g., Hayes v. Johnson, 578 F. Supp. 685, 689-90 (E.D. Mich. 1983). Accord Shell Oil Co. v. Superior Court, 213 Cal. 596, 2 P.2d 801 (1931).

220. Rosa v. Cantrell, 705 F.2d 1208, 1221 (10th Cir. 1982), cert. denied, 104 S.Ct. 85 (1983).

221. 578 F. Supp. 685 (E.D. Mich. 1983).

222. Id. at 688 .

223. Id. at 689 .

224. Id. at 690 .

225. Rosa v. Cantrell, 705 F.2d 1208, 1221 (10th Cir. 1982), cert. denied, 104 S. Ct. 85 (1983); Walker v. Rowe, 535 F. Supp. 55, 57 (N.D. Ill. 1982). 
ing state civil rights legislation or for invasions of privacy, ${ }^{226}$ most jurisdictions have apphied the alternative action theory because the supremacy clause does not mandate the use of the cumulative action theory. Under the alternative action theory, courts have not required plamtiffs to fit their cases within the intentional tort exception to the exclusive remedy clause. ${ }^{227}$ Instead, they have asked whether a discriminatory injury is a "personal injury,"228 and, if so, whether it "arises out of the scope of employment:",229

To determme whether a civil rights or privacy violation is a "personal mjury" covered by workers' compensation, some courts look to the various types of harm suffered by the plaintiff. They then apply a "merger doctrine." Under this doctrime, if the plaintiff has sustained a physical imjury or a mental disability covered by workers' compensation, the plaintiff is barred from brimging the civil rights or privacy action because all of the harms are deemed to have merged together. ${ }^{230}$ For example, because a worker who became sterile due to exposure to chemicals had suffered physical injury, he was not allowed to bring a privacy action for the demal of his fundamental right to procreate. ${ }^{231}$ And a woman who suffered an acute nervous breakdown following a discriminatory discharge was barred from recovering compensation for her general emotional distress under the Michigan Fair Employment Practices Act because her injury had culminated in a "disabling condition."232 It should be noted that in neither of the above cases did workers' compensation legislation provide a remedy for the harm to the plaintiff's dignitary interest. ${ }^{233}$

The problem with the "merger doctrime" is that it gives a preference to workers' compensation remedies when the plamtiff's injuries are covered by both workers' compensation and state civil rights legislation. ${ }^{234}$ To resolve this problem, other courts have given precedence to state civil

226. E.g., Cole v. Dow Chem. Co., 315 N.W.2d 565 (Mich. Ct. App. 1982) (violation of privacy interests).

227. See supra text accompanying notes 47-53, 82-92.

228. See supra text accompanying notes $98-118$.

229. See supra text accompanyimg notes 119-39. E.g., Williams v. United States, 565 F. Supp. 59 (N.D. Miss. 1983); Freeman v. Kelvinator, Inc., 469 F. Supp. 999 (E.D. Mich. 1979).

230. Williams v. United States, 565 F. Supp. 59 (N.D. Miss 1983); Cole v. Dow Chem. Co., 315 N.W.2d 565 (Mich. Ct. App. 1982).

231. Cole v. Dow Chem. Co., 315 N.W.2d 565 (Mich. Ct. App. 1982).

232. Stimson v. Michigan Bell Tel. Co., 258 N.W.2d 227 (Mich. Ct. App. 1977). The Michigan Supreme Court expressly disapproved the holding in Stimson in Boscaglia v. Michigan Bell Tel. Co., 362 N.W.2d 642 (Mich. 1984).

233. Cole, 315 N.W.2d at 569; Stimson, 258 N.W.2d at 232.

234. Boscaglia v. Michigan Bell Tel. Co., 362 N.W.2d 642 (Mich. 1984). See Freeman v. Kelvinator, Inc., 469 F. Supp. 999, 1000 (E.D. Mich. 1979) (discussiug in dictum the historical interpretation of workers' compensation and merger principles). 
rights legislation. ${ }^{235}$ These courts have been influenced by the cases which construe the supremacy clause as mandating a preference for federal constitutional rights over state no-fault legislation. ${ }^{236}$ They have developed two theories: (1) a "discrimination injury is unique,"237 and therefore not covered by workers' compensation; ${ }^{238}$ and (2) a civil rights injury does not arise out of einployment because it is "not a hazard of employment."239 Under these decisions, courts have granted relief for claims of sex discrimination, ${ }^{240}$ race discrimination, ${ }^{241}$ and denial of procedural due process ${ }^{242}$ despite the defendants' invocation of an exclusive remedy clause as an affirmative defense.

The problem with both of the above alternative action approaches is that they force a choice between either workers' coinpensation benefits or a civil rights remedy. Recent Michigan lower court decisions have found a way to permit plaintiffs to take advantage of both types of remedial laws - the cumulative remedy theory. ${ }^{243}$ Thus, in Pacheco v. Clifton, ${ }^{244}$ the court held that a plaintiff who had been the victim of national origin discrimination could recover workers' compensation benefits for the period of his'temporary physical disability as well as civil rights dainages, "particularly those resulting from humiliation, einbarrassment, . . . and lost wages." 245 The court explicitly rejected the merger doctrine. It held that the plaintiff could recover civil rights damages for "those injuries occurring prior to plaintiff's disability" as well as for "those occurring after his disability."246

The Michigan Supreme Court affirmed the decision in Pacheco $v$.

235. E.g., Freeman v. Kelvinator, Inc., 469 F. Supp. 999 (E.D. Mich. 1979).

236. See supra text accompanying notes 218-25.

237. Freeman v. Kelvinator, Inc., 469 F. Supp. 999,1000 (E.D. Mich. 1979).

238. DeFord v. Secretary of Labor, 700 F.2d 281 (6th Cir. 1983); Moll v. Parkside Livonia Credit Union, 525 F. Supp. 786 (E.D. Mich. 1981); Freeman v. Kelvinator, Inc., 469 F. Supp. 999 (E.D. Mich. 1979). See also Hamilton v. East Ohio Gas Co., 470 Ohio App. 2d 55, 351 N.E.2d 775 (1973).

239. Foley v. Polaroid Corp., 381 Mass. 545, 553, 413 N.E.2d 711, 716 (1980).

240. Moll v. Parkside Livoma Credit Union, 525 F. Supp. 786 (E.D. Mich. 1981).

241. Freeman v. Kelvinator, Inc., 469 F. Supp. 999 (E.D. Mich. 1979).

242. Grichenko v. United States Postal Serv., 524 F. Supp. 672 (E.D.N.Y. 1981), aff'd, 751 F.2d 368 (2d Cir. 1984).

243. Borchardt-Spicer v. G.A.F. Corp., 362 N.W.2d 728 (Mich. Ct. App. 1984); McCalla v. Ellis, 341 N.W.2d 525 (Mich. Ct. App. 1983); Slayton v. Michigan Host, Inc., 332 N.W.2d 498 (Mich. Ct. App. 1983); Pacheco v. Clifton, 311 N.W.2d 801 (Mich. Ct. App. 1981), affd, Boscaglia v. Michigan Bel1 Tel. Co., 362 N.W.2d 642 (Mich. 1984). For a discussion of McCalla and Slayton, see supra text accompanying notes 166-73.

244. 311 N.W.2d 801 (Mich. Ct. App. 1981), aff'd, Boscaglia v. Michigan Bell Tel. Co., 362 N.W.2d 642 (Mich. 1984).

245. Id. at 806 .

246. Id. 
Clifton, ${ }^{247}$ but it adopted the cumulative action theory rather than the cumulative remedy theory. The court ruled than an employee invoking an express or implied state statutory right to be protected against employment discrimination is exempt from the workers' compensation exclusivity provision. ${ }^{248}$ The court emphasized that the state civil rights acts are aimed at different evils from those at which the workers' compensation act is directed. ${ }^{249}$ The workers' compensation act 'guards against the victims of industrial injuries being 'turned away empty handed' . . . as a result of cominon-law tort doctrines such as contributory negligence and the fellow-servant rule."250 The civil rights acts, by contrast, are "addressed to the 'prejudices and biases' one race, sex or rehgion bears against another."251 The court concluded that the legislature did not intend for the objectives of the civil rights acts to be "defeated by the bar of the exclusive remedy provision of the workers' compensation act."252 Rather, the legislature intended for the civil rights legislation to "supersede or modify" the scope of the workers' compensation legislation. ${ }^{253}$ Thus, the court invoked the general principle that specific legislation supersedes or modifies general legislation. Just as all courts have adopted the cumulative action theory to protect federal rights, so the Michigan Supreme Court has now adopted the theory to protect statutory state civil rights.

The two opinions in Pacheco v. Cilfton invite a comparison of the cumulative action and cumulative remedy theories in the context of state civil rights hitigation. The cumulative action theory allows the state civil rights plaintiff to file first for workers' compensation benefits, and then to sue for civil rights damages. In the event of double recovery, the workers' compensation benefits are set off against the civil rights damages. The advantage of this procedure is that it provides maximum compensation for the victim of a civil rights violation. In addition, the civil rights action thereby has its maximum deterrent impact against the employer. The cumulative remedy theory, like the cumulative action theory, permits the employee to recover civil rights damages without foregoing any applicable workers' compensation benefits. Unlike the cumulative action theory, however, the cumulative remedy theory preserves the limitation on an employer's liability for physical or mental disabilities, which is a central feature of workers' compensation legislation. Under the cumula-

247. Boscaglia v. Michigan Bell Tel. Co., 362 N.W.2d 642 (Mich. 1984), affg Pacheco v. Clifton, 336 N.W.2d 849 (1980) (Pacheco was consolidated with Boscaglia).

248. Id.

249. Id. at 645 .

250. Id.

251. Id.

252. Id. at 646 .

253. Id. 
tive remedy theory, the employer is subjected to open-ended liability only for the dignitary and punitive damages flowing directly from the civil rights violation. Thus, the cumulative remedy theory attempts to reconcile the conflict between state civil rights legislation and the exclusive remedy clause, whereas the cumulative action theory gives priority to the state civil rights legislation.

\section{Offensive Battery, Assault, and Intentional Infliction of Emotional Distress}

Offensive battery and assault are torts commited with the intent to cause offensive contact or the apprehension of either harmful or offensive contact. ${ }^{254}$ An action for intentional infliction of emotional distress requires proof that the defendant engaged in extreme and outrageous conduct with the intent to cause severe emotional distress. ${ }^{25 s}$ Only twice has the cumulative action theory ${ }^{256}$ been applied to any of these three causes of action. ${ }^{257}$ Most complaints alleging one of these three causes of action have been examined under the alternative action theory. ${ }^{258}$

Claims for assault, offensive battery, and intentional infliction of emotional distress present thorny problems in drawing a line between tort liability and no-fault benefits because they are frequently brought for a inixture of physical and nonphysical harm. ${ }^{259}$ When actions for false imprisonment, defamation, and civil riglits violations are brought for both physical and nonphysical harm, most courts are willing to look to the "gist of the claim" and permit a plaintiff to proceed in tort to vindicate the dignitary imterest. ${ }^{260}$ But im actions for assault, offensive battery and intentional infliction of emotional distress, the essence of the claim is mental harm, rather than a specific dignitary interest. ${ }^{261}$ For this reason, the courts have tended to liold that these are claims for "personal injury" covered by workers' compensation. The tendency is particularly pro-

254. Prosser \& KeETON, supra note $174, \S \S 9-10$.

255. Id. § 12, at 60. See generally Givelben, The Right to Minimum Social Decency and the Limits of Evenhandedness: Intentional Infiction of Emotional Distress by Outrageous Conduct, 82 COLUM. L. Rev. 42 (1982).

256. See supra text accompanying notes 23-46.

257. Young v. Libby-Owens Ford Co., 214 Cal. Rptr. 400 (Cal. Ct. App. 1985); McGee v. McNally, 119 Cal. App. 3d 891, 174 Cal. Rptr. 253 (1981); see also supra text accompanying notes 41-42.

258. See supra text accompanying notes 68-139.

259. E.g., Vigil v. Safeway Stores, Inc., 555 F. Supp. 1049 (D. Colo. 1983); Stewart v. McLellan's Stores Co., 194 S.C. 50, 9 S.E.2d 35 (1940).

260. See supra text accompanying notes 185-86, 202-03, 234-42.

261. See Kissinger v. Mannor, 285 N.W.2d 214 (Mich. Ct. App. 1979). Battery and assault are better suited than intentional infiction of emotional distress to protecting dignitary interests, because nominal damages are recoverable in battery and assault actions. E.g., Brown v. Stauffer Chem. Co., 167 Mont. 418, 539 P.2d 374 (1975). 
nounced if the complaint alleges physical mjury ${ }^{262}$ or if the jurisdiction allows no-fault benefits for mental harm caused by a mental or physical stimulus. $^{263}$

Professor Larson has suggested the following solution to the dileinma presented by nonphysical intentional tort actions for mixed types of harm under the alternative action theory:

If the essence of the tort, in law, is non-physical, and if the injuries are of the usual non-physical sort, with physical injury being at nost added to the list of injuries as a makeweight, the suit should not be barred. But if the essence of the action is recovery for physical injury or death, the action should be barred even if it can be cast in the form of a normally non-physical tort. ${ }^{264}$

Professor Larson's solution is not particularly satisfactory because it conditions the opportumity to brimg an alternative action upon the absence of physical injury. The more physical the harm, the less hikely that the plaintiff will be allowed to proceed in tort. ${ }^{265}$ Yet it is precisely in cases of egregious misconduct resulting in physical as well as nonphysical harm that tort damages seem most appropriate to vindicate the victim and to punish the perpetrator.

There are several potential solutions that would be preferable to Professor Larson's. First, because assault, offensive battery, and intentional infliction of eniotional distress are all intentional tort actions, a court could permit a plaintiff to brimg an alternative action based upon proof of intent. ${ }^{266}$ Second, if the legislature's general policy were to

262. Burbank v. Mutual of Omaha Ius. Co., 484 F. Supp. 693 (N.D. Ga. 1979), affd, 616 F.2d 565 (5th Cir. 1980); Hollywood Refrigeration Sales Co. v. Superior Court, 164 Cal. App. 3d 754, 210 Cal. Rptr. 619 (1985); Gates v. Trans Video Corp., 93 Cal. App. 3d 196, 155 Cal. Rptr. 486 (1979); Ankeuy v. Lockheed Missiles \& Space Co., 88 Cal. App. 3d 531, 151 Cal. Rptr. 828 (1979); Kandt v. Evans, 645 P.2d 1300 (Colo. 1982); Ellis v. Rocky Mountain Empire Sports, Inc., 43 Colo. App. 166, 602 P.2d 895 (1979).

263. See Crews v. Memorex Corp., 588 F. Supp. 27 (D. Mass. 1984); Foley v. Polaroid Corp., 381 Mass. 545, 413 N.E.2d 711 (1980); cf. Burbank v. Mutual of Omaha Ins. Co., 484 F. Supp. 693 (N.D. Ga. 1979), affd, 616 F.2d 565 (5th Cir. 1980).

264. 2A A. LARSON, supra note 1, \& 68.34(a) (1983).

265. The Michigan Supreme Court has voiced a comparable criticism of Professor Larson's theory as applied to civil rights actions in Stimson v. Michigan Bell Tel. Co., 258 N.W.2d 227 (Mich. Ct. App. 1977):

The Stimson distinction [between "disabling conditions" and "nondisabling discriminatory injuries"] would yield anomalous results. Where employment discrimination causes injuries that are not so severe as to culminate in disability, the mjured employee would be permitted to sue his employer in tort and recover full damages; however, where the injuries suffered are so severe as to culminate in disability, the injured employee would be restricted to workers' compensation benefits.

Boscaglia v. Michigan Bell Tel. Co, 362 N.W.2d 642, 648 (Mich. 1984).

266. E.g., Brown v. Winn-Dixie Montgomery, Inc., 427 So. $2 d 1065$ (Fla. Dist. Ct. App. 1983); Smith v. Rich's, Inc., 104 Ga. App. 883, 123 S.E.2d 316 (1961); Maggio v. St. Francis Medical Center, 391 So. 2d 948 (La. Ct. App. 1980), cert. denied, 396 So.2d 1351 (La. 1981); Schutt v. Lado, 360 N.W.2d 214 (Mich. Ct. App. 1984); Leopold v. Britt, 58 A.D.2d 856, 396 N.Y.S.2d 680 (1977). 
allow no-fault benefits for intentional torts, an alternative action could be recognized whenever the defendant's conduct was so egregious that the injury "did not arise out of the scope of the einployinent," of sexual harassment. ${ }^{268}$ Third, a court that focused exclusively on the type of harm sustained could distinguish between "1nental disability" and "general emotional distress." Workers' coinpensation would cover cases of "physical or mental disability," while suits for "general emotional distress" would be actionable in tort. ${ }^{269}$ Finally, a court could invoke the cumulative remedy theory. ${ }^{270}$ Under it, workers' compensation benefits would be available for physical and inental disabilities. At the same time, a plamtiff could pursue a tort action for either nominal damages or general einotional distress damages, plus pumtive damages whenever the requisite malice could be shown.

\section{E. Bad-Faith Refusal to Pay or Delay in Paying Workers' Compensation Claim}

An offshoot of the action for intentional infliction of emotional distress is an action against a liability or loss insurer for bad faith in processing an insurance claim. ${ }^{271}$ Specifically, in the workers' compensation context, an employee inay bring an action against a workers' compensation insurer (or an employer) for a refusal to pay workers' compensation benefits, a delay im payinent, a fraudulent investigation, or a wrongful termination of benefits designed to coerce a settlement. ${ }^{272} \mathrm{~A}$ bad-faith action may be based upon proof of neghigence, ${ }^{273}$ fraud ${ }^{274}$ or intent. ${ }^{275}$

The first case to recognize a bad faith action against a workers' compensation carrier was Unruh v. Truck Insurance Exchange. ${ }^{276}$ Despite

These cases adopt the approach to recognizing an alternative tort action that is discussed in text accompanying notes $82-92$ supra.

267. E.g., Iverson v. Atlas Pac. Eng'g, 143 Cal. App. 3d 219, 191 Cal. Rptr. 696 (1983); Lagies v. Copley, 110 Cal. App. 3d 958, 168 Cal. Rptr. 368 (1980). These cases adopt the approach to recognizing an alternative tort action that is discussed in text accompanying notes 119-39 supra.

268. E.g., Bennet v. Furr's Cafeterias, Inc., 549 F. Supp. 887 (D. Colo. 1982); Skousen v. Nidy, 90 Ariz. 215, 367 P.2d 248 (1961).

269. Schroeder v. Dayton-Hudson Corp., 456 F. Supp. 652 (E.D. Mich. 1978); Ritter v. Allied Chem. Corp., 295 F. Supp. 1360 (D.S.C. 1968), affd, 407 F.2d 403 (4th Cir. 1969); Renteria v. County of Orange, 82 Cal. App. 3d 833, 147 Cal. Rptr. 447 (1978); Kissinger v. Mannor, 285 N.W.2d 214 (Mich. Ct. App. 1979). These cases adopt the approach to recognizing an alternative tort action that is discussed in text accompnaying notes 112-14 supra.

270. See supra text aecompanying notes 140-73.

271. See generally Annot., 8 A.L.R.4th 902 (1981); Schuessler, First Party Bad Faith: Should It Be Extended to Workers' Compensation Cases? 34 Fed'N INs. Couns. Q. 199 (1984).

272. 2A A. LARSON, supra note $1, \S \S 68.34(\mathrm{~b})$-(c) (1983).

273. E.g., Savio v. Travelers Ins. Co., 678 P.2d 549 (Colo. Ct. App. 1983).

274. E.g., DeMarco v. Federal Ins. Co., 99 A.D.2d 114, 472 N.Y.S.2d 464 (1984).

275. E.g., Gibson v. Fidelity \& Cas. Co., 454 So. $2 d 526$ (Ala. 1984); Garvin v. Shewbart, 442 So. 2 d 80 (Ala. 1983).

276. 7 Cal. 3d 616, 498 P.2d 1063, 102 Cal. Rptr. 815 (1972). 
an exclusive remedy clause protecting insurers, the Cahfornia Suprene Court permitted the plaintiff to bring a cumulative action against a carrier who conducted a fraudulent investigation of the einployee's no-fault clain. Thus, the plaintiff was entitled to recover tort damages in addition to the workers' coinpensation benefits that she had already received for both the original industrial injury and the mental breakdown resulting froin the fraudulent investigation. To avoid double recovery, the court required that the no-fault benefits awarded for her breakdown be set off against the bad-faith tort damages.

The Unruh court distinguished between "negligent" and "intentional" Inisconduct, stating that only proof of intent would justify a cuinulative tort action. ${ }^{277}$ The highest courts of Alaska ${ }^{278}$ and Maine ${ }^{279}$ have followed Unruh, recognizing a cuinulative action for an insurer's intentional misconduct. Subsequent cases from Cahfornia ${ }^{280}$ and other jurisdictions ${ }^{281}$ have interpreted Unruh 1nore restrictively, however, requiring proof of "fraudulent, deceitful, outrageous [or] perfidious" tortious acts by the insurer. ${ }^{282}$ The California Supreme Court was recently deprived of an opportunity to resolve this dispute over the requisite state of inind when the parties in Palmer v. R.L. Kautz \& Co. settled the case while the appeal was pending. ${ }^{283}$

Although the cumulative action theory was the original theory of recovery in the bad-faith cases, the majority of jurisdictions now apply the alternative action theory. It is therefore important to examine the workers' coinpensation remedies for bad-faith conduct by insurers. Most legislatures have enacted workers' compensation provisions designed to encourage good-faith conduct by insurers. ${ }^{284}$ Several jurisdictions have an explicit statutory procedure whereby an employee may coerce compli-

277. Id. at $630,498 \mathrm{P} .2 \mathrm{~d}$ at 1073, 102 Cal. Rptr. at 825.

278. Stafford v. Westchester Fire Ins. Co., 526 P.2d 37, 43 (Alaska 1974).

279. Gibson v. National Ben Franklin Ins. Co., 387 A.2d 220, 223 (Me. 1978).

280. Goetz y. Aetna Cas. \& Sur. Co., 710 F.2d 561, 565 (9th Cir. 1983); Argonaut Ins. Co. v. Superior Court, 164 Cal. App. 3d 320, 324, 210 Cal. Rptr. 417, 420 (1985); Gallo Glass Co. v. Superior Court, 148 Cal. App. 3d 485, 488, 196 Cal. Rptr. 23, 25 (1983); Cervantes v. Great Am. Ins. Co., 140 Cal. App. 3d 763, 768, 189 Cal. Rptr. 761, 764 (1983); Droz v. Pacific Nat'1 Ins. Co., 138 Cal. App. 3d 181, 184-85, 188 Cal. Rptr. 10, 12 (1982); Depew y. Hartford Acc. \& Indem. Co., 135 Cal. App. 3d 574, 576-77, 185 Cal. Rptr. 472, 473-74 (1982); Fremont Indem. Co. v. Superior Court, 133 Cal. App. 3d 879, 184 Cal. Rptr. 184 (1982); Ricard v. Pacific Indem. Co., 132 Cal. App. 3d 886, 893, 183 Cal. Rptr. 502, 506 (1982); Everfield v. State Compensation Ins. Fund, 115 Cal. App. 3d 15, 18, 171 Cal. Rptr. 164, 165 (1981).

281. E.g., Sandoval v. Salt River Project Agricultural Improvement and Power Dist., 117 Ariz. 209, 571 P.2d 706 (1977); Denisen v. Milwaukee Mut. Ins. Co., 360 N.W.2d 448 (Minn. Ct. App. 1985).

282. Everfield v. State Compensation Ins. Fund, 115 Cal. App. 3d 15, 19, 171 Cal. Rptr. 164, 165 (1981).

283. Palmer v. R.L. Kautz \& Co., 190 Cal. Rptr. 139 (1983) (hearing granted; appeal dismissed due to settlement).

284. See generally Annot., 8 A.L.R.4th 902, § 5 (1981). 
ance with the rules governing payment of workers' compensation benefits. ${ }^{285}$ An increasing number of jurisdictions also have enacted a statutory penalty for inexcusable delay in processing workers' compensation claims. ${ }^{286}$ Courts in these states frequently have held these remedies to be exclusive, barring tort actions for both negligent and intentional misconduct by the insurer. ${ }^{287}$ They have distinguished the harm caused by the insurer's bad faith from the industrial injury. These courts have concluded that the exceptions to the exclusive remedy clause apply only when the employee is suing the employer for the industrial injury. Thus, these courts have refused to authorize a bad-faith tort action (1) under a workers' compensation provision recognizing an intentional tort exception to the exclusive remedy clause governing industrial injuries, ${ }^{288}$ or (2) as an action outside the scope of an exclusive remedy clause that covers only "accidental injuries" or injuries "arising out of" the employment relationship. ${ }^{289}$

Other courts faced with a statutory coercive remedy or penalty provision have adopted a completely contrary approach. They have permitted an employee to elect between a workers' compensation remedy and tort damages for the insurer's failure to process a claim promptly. ${ }^{290}$ In justifying the alternative action theory, they have invoked the traditional exceptions to the exclusive remedy clause. ${ }^{291}$ Recognizing that the type of harm sustained is covered by a coercive remedy or statutory penalty, these courts have held that the statutory reinedy is not exclusive because.

285. For example, New Mexico law allows for an expedited hearing and judgment by a district court when the employee files a claim to collect for nonpayment. N.M. STAT. ANN. $\$ \$ 52-1-31$ to -39 (1978 \& Supp. 1984); see also Chavez v. Kennecott Copper Corp., 547 F.2d 541 (10th Cir. 1977) (New Mexico law); Dickson v. Mountain States Mut. Cas. Co., 98 N.M. 479, 650 P.2d 1 (1982).

286. E.g., CaL LAB. Code $\S \S 5814,5814.1,5814.5$ (West 1971 \& Supp. 1985); see also Robertson v. Travelers Ins. Co., 95 Ill. 2d 441, 448 N.E.2d 866 (1983).

287. Escobedo v. American Employers Ins. Co., 547 F.2d 544 (10th Cir. 1977) (New Mexico law); Chavez v. Kennecott Copper Corp., 547 F.2d 541 (10th Cir. 1977) (New Mexico law); Whitten v. American Mut. Liab. Ins. Co., 468 F. Supp. 470 (D.S.C. 1977), aff'd, 594 F.2d 860 (4th Cir. 1979); Strickland v. Birmingham Bldg. \& Remodeling, 449 So. 2d 1242 (Ala. 1984); Brown v. Transportation Ins. Co, 448 So. 2d 348 (Ala. 1984); Waldon v. Hartford Ins. Group, 435 So. 2d 1271 (Ala. 1983); Sandoval v. Salt River Project Agricultural Improvement \& Power Dist., 117 Ariz. 209, 571 P.2d 706 (Ct. App. 1977); Hixon v. State Compensation Fund, 115 Ariz. 392, 565 P.2d 898 (Ct. App. 1977); Garrett v. Washimgton Air Compressor Co., 466 A.2d 462 (D.C. 1983); Old Republic Ins. Co. v. Whitworth, 442 So. 2d 1078 (Fla. Dist. Ct. App. 1983); Bright v. Nimmo, 253 Ga. 378, 320 S.E.2d 365 (1984); Robertson v. Travelers Ins. Co., 95 Ill. 2d 441, 448 N.E.2d 866 (1983); Taylor v. United States Fid. \& Guar. Co., 420 So. 2d 564 (Miss. 1982); Young v. United States Fid. \& Guar. Co., 588 S.W.2d 46 (Mo. Ct. App. 1979); Dickson v. Mountain States Mut. Cas. Co., 98 N.M. 479, 650 P.2d 1 (Ct. App. 1982); Gonzales v. United States Fid. \& Guar. Co., 99 N.M. 432, 659 P.2d 318 (Ct. App. 1983).

288. Hollman v. Liberty Mut. Ins. Co., 712 F.2d 1259, 1261 n.4 (8th Cir. 1983) (South Dakota law).

289. Robertson v. Travelers Ins. Co., 95 Ill. 2d 441, 448 N.E.2d 866 (1983).

290. Savio v. Travelers Ins. Co., 678 P.2d 549 (Colo. Ct. App. 1983).

291. See supra text accompanying notes 76-139. 
the defendant's act was "intentional"292 or "callous."293 They have reasoned that "[i]t was never intended that injuries thus caused were to be exclusively the province of the Workers' Compensation Board."

In recent years, an increasing number of jurisdictions have refused to require an election between a workers' compensation remedy and tort damages for acts of bad faith. Instead, they have applied the cumulative remedy theory. ${ }^{295}$ Specifically, in addition to relief under the coercive remedy or statutory penalty provisions, they have permitted the employee to proceed in tort for the intentional infliction of emotional distress. ${ }^{296}$ Some courts have emphasized the nonphysical nature of the emotional distress damages, ${ }^{297}$ noting that they are not coinpensable under workers' compensation:

The essence of the tort alleged, and the damage alleged, is nonphysical. This is not an action for mental damages incidentally resulting from an industrial injury. Were we to hold otherwise, einployers and insurance companies could, with inipunity, withhold benefits for undeniably con1pensable injuries until ordered to pay benefits by the Workers' Conipensation referee or Appeal Board. . . . We do not find such a result to comport either with the intent of the Act or with the public interest. ${ }^{298}$

Other courts have focused on the intentional or outrageous quality of the defendant's conduct. ${ }^{299}$ They have permitted the einployee to recover both the statutory penalty and tort damages because "the [penalty provision] does not contemplate that the intentional tort of bad faith can be expiated merely by payments augmented in the amount of 10 percent." ${ }^{300}$

The cumulative reinedy theory is particularly appropriate for badfaith litigation. It recognizes workers' coinpensation as the primary rem-

292. DeMarco v. Federal Ins. Co., 99 A.D.2d 114, 472 N.Y.S.2d 464 (1984).

293. Martin v. Travelers Ins. Co., 497 F.2d 329 (1st Cir. 1974) (Longshoremen's and Harbor Workers' Compensation Act).

294. DeMarco v. Federal Ins. Co., 99 A.D.2d 114, 117, 472 N.Y.S.2d 464, 466 (1984).

295. See supra text accompanying notes 140-73.

296. E.g., Garvin v. Shewbart, 442 So. 2d 80 (Ala. 1983); Burlew v. American Mut. Ins. Co., 64 N.Y.2d 412, 472 N.E.2d 682, 482 N.Y.S.2d 720 (1984).

297. Broaddus v. Ferndale Fastener Div., 269 N.W.2d 689 (Mich. Ct. App. 1978).

298. Id. at 693.

299. Hollman v. Liberty Mut. Ins. Co., 712 F.2d 1259 (8th Cir. 1983) (South Dakota law); Reed v. Hartford Accident \& Indem. Co., 367 F. Supp. 134 (E.D. Pa. 1973); Garvin v. Shewbart, 442 So. 2d 80 (Ala. 1983); Birkenbuel v. Montana State Compensation Ins. Fund, 687 P.2d 700 (Mont. 1984); Hayes v. Aetna Fire Underwriters, 187 Mont. 148, 609 P.2d 257 (1980); Massey v. Armco Steel Co., 652 S.W.2d 932 (Tex. 1983); Fidehity \& Cas. Co. v. Shubert, 646 S.W.2d 270 (Tex. Ct. App. 1983).

300. Coleman v. American Universal Ins. Co., 86 Wis. 2d 615, 625, 273 N.W.2d 220, 224 (1979). The Wisconsin legislature subsequently enacted a stiffer penalty provision. WIs. STAT. ANN. $\S 102.18(\mathrm{a})$ (bp) (West Supp. 1984). It is now the exclusive remedy for a bad-faith denial of workers' compensation. Messner v. Briggs \& Stratton Corp., 120 Wis. 2d 127, 353 N.W.2d 363 (Ct. App. 1984). 
edy, thereby encouraging the legislature to enact a statutory penalty for inexcusable delay in processing an einployee's clain for the original industrial injury. If the legislature fails to enact a statutory penalty, the tort relnedy is available as a deterrent to acts of bad faith by the compensation carrier. If a penalty is enacted, but proves to be ineffective against a recalcitrant insurer, the tort remedy inay be invoked to punish especially egregious inisconduct.

In bad-faith actions, the cumulative remedy is also easier to administer than the cumulative action theory. The cumulative action theory requires the court to determine what percentage of workers' coinpensation benefits were awarded for the aggravation of the industrial injury by the insurer's acts of bad faith, and to set off that percentage against the tort damages. ${ }^{301}$ Furthermore, the court must decide whether to offset any statutory penalty against the tort recovery. Under the cumulative remedy theory, by contrast, workers' compensation benefits are awarded solely for the original industrial injury, and not for the insurer's acts of bad faith. ${ }^{302}$ If there is a workers' compensation penalty, it is not set off agamst the tort recovery because the penalty is regarded as an administrative fine rather than as compensatory or punitive damages.

\section{III \\ LEGISLATIVE OPTIONS}

This Article has analyzed various options for preserving tort liability for nonphysical harm. A legislature could adopt any one of them. It could authorize a cumulative action, an alternative action, or a cumulative remedy. Nor is it necessary for a legislature to select a single approach to preserving tort liability for all nonphysical harms. It may adopt different options for different causes of action. The choice will depend not only upon considerations of administrative efficiency, but also upon the value that the legislature attributes to the interests protected by the various tort actions for nonphysical harm. This Section of the Article will evaluate the different options and will highlight the factors that the legislature should consider in choosing among thein.

\section{A. Cumulative Action}

The cumulative action has the maximum coinpensatory, deterrent, and punitive mipact. The plaintiff is permitted to obtain a tort judgment for full compensatory damages plus punitive damages (if they are appropriate), with a set-off for no-fault benefits. The cumulative action is also

301. Unruh v. Truck Ins. Exchange, 7 Cal. 3d 616, 636, 498 P.2d 1063, 1077-78, 102 Cal. Rptr. 815, 829, (1972).

302. Coleman v. American Universal Ins. Co., 86 Wis. 2d 615, 624, 273 N.W.2d 220, 223 (1979). 
generally the easiest to administer because the injured person may process claims for no-fault benefits and tort damages simultaneously. Furthermore, the legislature need not draw a line between the spheres of nofault coverage and tort liabihty. The cumulative action theory conflicts, however, with the no-fault objective of hmiting a defendant's tort liability for compensatory damages. Therefore, the theory should be recognized only to protect highly valued interests or to punish and deter serious misconduct.

The cumulative action was first recognized for deliberately inflicted physical injury and outrageous conduct designed to cause severe emotional distress. It can be tailored to other types of fact situations, as evidenced by the cases authorizmg cumulative civil rights actions. A legislature wishing to exercise this option should focus on three issues. First, it must define the nature of the interest to be protected by the cumulative action. The no-fault legislation could permit tort liability only for specific interests, such as constitutional rights, or, more generally, for all types of nonphysical harm. The second issue is the nature of the defendant's conduct. Due to the historical origins of the cumulative action theory, it is associated with proof of specific intent to injure or of egregious inisconduct. A cumulative action also could be premised upon ordinary proof of intent or recklessness, however, and tliere is no need to impose a requirement of outrageous conduct outside the context of an action for intentional infliction of emotional distress. The third issue is the relationship between the tort action and any statutory penalty that the state may have adopted as part of its no-fault plan. The legislature should specify whether the injured person is entitled to both the statutory penalty and tort dainages, or whether the penalty is to be set off against the tort recovery.

\section{B. Alternative Action}

The authorization of a cumulative action can be criticized as too generous, and it certainly conflicts witl the no-fault objective of limiting a defendant's tort liability for compensatory damages. The alternative action represents a more conservative approach, under which the defendant is subjected to tort liabihity ouly when no-fault benefits are not available. The alternative action is the inost widely used theory im claims for nonphysical harm.

Because the alternative action theory requires a clioice between tort liability and no-fault coverage, a legislature adopting the theory must carefully distinguisl between them. One approach is to draw the line by reference to the type of interest to be protected. A legislature drawing this sort of line could authorize tort actions for all types of nonphysical harm. Alternatively, it could create tort hability for specific causes of 
action, such as defamation, false imprisonment, and civil rights violations. It should be noted that it is easier to draw the line with reference to actions for dignitary harm than for emotional distress. In the former, the legislature can focus on the essence of the tort (e.g., harm to reputation), while in the latter, it must distinguish between general emotional distress, which is actionable in tort, and mental or physical disability, which is compensable under the no-fault plan.

Because it is so difficult to draw the line between tort and no-fault on the basis of the type of interest to be protected, the legislature may prefer to focus on the nature of the defendant's conduct, requiring proof of intent or recklessness. The problein with this approach is that some tort actions for nonphysical harm, such as defamation and constitutional tort actions, do not require proof of intent as part of the prima facie case. To encoinpass these actions, the legislature could impose tort liability for any misconduct that does not arise out of, and in the course of, employment. This inethod of demarcating the boundary between tort and nofault encourages the decisionmaker to take into account the policy considerations underlying the no-fault plan.

\section{Cumulative Remedy}

The primary problem with the alternative action theory is that it inandates a choice between tort and no-fault. A plaintiff who wishes to vindicate dignitary interests or punish the defendant through punitive damages must forego no-fault benefits as compensation for actual harm. The cuinulative reinedy theory resolves this dilemma. It allows the nofault plan to perform the compensatory function which it was designed to serve, and authorizes the tort systein to vindicate dignitary interests and pumish egregious inisconduct. Instead of forcing a choice between tort and no-fault, the cumulative remedy permits the claimant to recover no-fault benefits for those harms covered by the plan, and tort damages for those harms which fall outside the scope of the plan. Also, the cumulative remedy theory encourages the establishinent of no-fault penalties. The no-fault penalty can be viewed as an administrative fine, with punitive damages available as a backup in cases of the inost egregious conduct.

In drafting cumulative reinedy legislation, it is necessary to define the line between tort hability and no-fault coverage because all harms not covered by the no-fault plan will be actionable in tort. The initial line inust be drawn by reference to the type of interest to be protected, even though the preceding discussion of the alternative action theory has emphasized that such a line is soinetimes difficult to draw. Thus, the nofault plan could cover only physical disability, or it could cover both physical and mental disabilities. If it covers mental disabilities, the legis- 
lature should specify the circumstances under which tort actions for nonphysical harm are appropriate. There are several options. First, the legislature could decide to permit tort actions only for nominal plus pumtive damages. No-fault benefits would be the exclusive source of compensation for nonphysical harm. Second, the legislature could authorize tort actions for nominal and punitive damages plus compensatory damages to cover dignitary interests (e.g., harm to reputation) and general emotional distress. Third, the legislature could authorize tort actions for nonphysical harm only upon proof of intent or recklessness.

Once the legislature has determined which harms are covered by the no-fault plan and which harms are compensable in tort, then it should address tort liability for punitive damages. If it makes the no-fault plan the sole source of compensation, the legislature should consider authorizing the recovery of punitive damages in tort upon proof of either nominal damages or actual harm (even though the harm is compensated by the no-fault plan). ${ }^{303}$ And if the no-fault plan contains statutory penalties, ${ }^{304}$ the legislature should specify whether punitive damages are available im addition to the no-fault penalties, or whether the statutory penalty is the exclusive punitive remedy.

\section{CONCLUSION}

Of the three theories which currently authorize a tort action for nonphysical harm after the adoption of a no-fault compensation plan, the cumulative remedy theory best serves the objectives of both the tort and no-fault systems. It retains the limitations on liability that are an essential part of any no-fault plan. Yet it also permits the imposition of tort liability on defendants who would otherwise enjoy immunity under the no-fault plan's exclusive remedy provision. Thus, it maximizes the use of no-fault legislation to compensate for physical and mental disabilities. At the same time, it preserves the traditional vindicatory and punitive functions of tort liability.

303. See generally Love, supra note 17, at 244-51.

304. Id. at 251-52. 